\title{
Calcium entry units (CEUs): perspectives in skeletal muscle function and disease
}

\author{
Feliciano Protasi $^{1,2}$ (D) Laura Pietrangelo ${ }^{1,2} \cdot$ Simona Boncompagni ${ }^{1,3}$
}

Received: 3 April 2020 / Accepted: 3 August 2020 / Published online: 18 August 2020

(c) The Author(s) 2020

\begin{abstract}
In the last decades the term Store-operated $\mathrm{Ca}^{2+}$ entry (SOCE) has been used in the scientific literature to describe an ubiquitous cellular mechanism that allows recovery of calcium $\left(\mathrm{Ca}^{2+}\right)$ from the extracellular space. SOCE is triggered by a reduction of $\mathrm{Ca}^{2+}$ content (i.e. depletion) in intracellular stores, i.e. endoplasmic or sarcoplasmic reticulum (ER and SR). In skeletal muscle the mechanism is primarily mediated by a physical interaction between stromal interaction molecule-1 (STIM1), a Ca ${ }^{2+}$ sensor located in the SR membrane, and ORAI1, a Ca ${ }^{2+}$-permeable channel of external membranes, located in transverse tubules (TTs), the invaginations of the plasma membrane (PM) deputed to propagation of action potentials. It is generally accepted that in skeletal muscle SOCE is important to limit muscle fatigue during repetitive stimulation. We recently discovered that exercise promotes the assembly of new intracellular junctions that contains colocalized STIM1 and ORAI1, and that the presence of these new junctions increases $\mathrm{Ca}^{2+}$ entry via ORAI1, while improving fatigue resistance during repetitive stimulation. Based on these findings we named these new junctions $\mathrm{Ca}^{2+}$ Entry Units (CEUs). CEUs are dynamic organelles that assemble during muscle activity and disassemble during recovery thanks to the plasticity of the SR (containing STIM1) and the elongation/retraction of TTs (bearing ORAI1). Interestingly, similar structures described as SR stacks were previously reported in different mouse models carrying mutations in proteins involved in $\mathrm{Ca}^{2+}$ handling (calsequestrin-null mice; triadin and junctin null mice, etc.) or associated to microtubules (MAP6 knockout mice). Mutations in Stiml and Orail (and calsequestrin-1) genes have been associated to tubular aggregate myopathy (TAM), a muscular disease characterized by: (a) muscle pain, cramping, or weakness that begins in childhood and worsens over time, and (b) the presence of large accumulations of ordered SR tubes (tubular aggregates, TAs) that do not contain myofibrils, mitochondria, nor TTs. Interestingly, TAs are also present in fast twitch muscle fibers of ageing mice. Several important issues remain unanswered: (a) the molecular mechanisms and signals that trigger the remodeling of membranes and the functional activation of SOCE during exercise are unclear; and (b) how dysfunctional SOCE and/or mutations in Stim1, Orail and calsequestrin (Casq1) genes lead to the formation of tubular aggregates (TAs) in aging and disease deserve investigation.
\end{abstract}

Keywords Sarcoplasmic reticulum (SR) - Store-operated $\mathrm{Ca}^{2+}$ entry (SOCE) $\cdot$ Transverse tubules (TT) · Tubular aggregate myopathy (TAM)

Feliciano Protasi

feliciano.protasi@unich.it

1 CAST, Center for Advanced Studies and Technology, University G. d'Annunzio of Chieti-Pescara, 66100 Chieti, Italy

2 DMSI, Department of Medicine and Aging Sciences, University G. d'Annunzio of Chieti-Pescara, 66100 Chieti, Italy

3 DNICS, Department of Neuroscience, Imaging and Clinical Sciences, University G. d'Annunzio of Chieti-Pescara, 66100 Chieti, Italy

\begin{tabular}{ll}
\multicolumn{2}{l}{ Abbreviations } \\
CASQ1 & Calsequestrin-1 \\
CEU & Calcium entry unit \\
CRU & $\mathrm{Ca}^{2+}$ release unit \\
EDL & Extensor digitorum longus \\
EC Coupling & Excitation-contraction coupling \\
EM & Electron microscopy \\
ER & Endoplasmic reticulum \\
FDB & Flexor digitorum brevis \\
PM & Plasma membrane \\
SOCE & Store operated Ca ${ }^{2+}$ entry \\
SR & Sarcoplasmic reticulum \\
STIM1 & Stromal interaction molecule-1
\end{tabular}


TA

TAM

TT

Tubular aggregate

TA myopathy

Transverse tubule

\section{Store-operated $\mathrm{Ca}^{2+}$ entry in skeletal muscle function and disease}

\section{Store-operated $\mathrm{Ca}^{2+}$ entry (SOCE)}

Store-operated $\mathrm{Ca}^{2+}$ entry (SOCE), first described as capacitative $\mathrm{Ca}^{2+}$ entry in non-excitable cells (Putney 1986), is one of main $\mathrm{Ca}^{2+}$ entry mechanisms in cells that allow the replenishment of intracellular stores, i.e. the endoplasmic reticulum (ER). After the initial discovery, it was shown that $\mathrm{Ca}^{2+}$ release-activated calcium (CRAC) channels were involved in the mechanism (Hoth and Penner 1992). Then, the molecular bases of SOCE remained elusive for more than a decade, until the molecular players of SOCE were finally identified: (a) stromal interaction molecule-1 (STIM1), a $\mathrm{Ca}^{2+}$ sensor in the ER membrane (Liou et al. 2005; Roos et al. 2005; Zhang et al. 2005) and (b) ORAI1, a $\mathrm{Ca}^{2+}$-permeable channel (CRAC) of the plasma membrane (PM) (Prakriya et al. 2006; Vig et al. 2006; Wu et al. 2006; Yeromin et al. 2006). It is now becoming clear that SOCE may contribute to a variety of $\mathrm{Ca}^{2+}$ dependent cell functions such as gene transcription, migration, proliferation, differentiation, and also muscle contractility (Courjaret and Machaca 2012; Lopez et al. 2020; Moccia et al. 2012; Moccia et al. 2016; Ong et al. 2019; Potier et al. 2009; Stiber et al. 2008).

The mechanism that leads to activation of SOCE was first studied in non-excitable cells by light microscopy using fluorescent-tagged proteins. Briefly, upon $\mathrm{Ca}^{2+}$ depletion of internal stores, $\mathrm{Ca}^{2+}$ dissociates from the $\mathrm{N}$-terminal EF-hand domains of STIM1 located in the lumen of the ER (Liou et al. 2005). This leads to conformational changes with consequent dimerization of STIM1 in the ER membrane and translocation towards the PM enabling STIM1 to interact and activate ORAI1 $\mathrm{Ca}^{2+}$ channels. This STIM1-ORAI1 interaction occurs in discrete junctional regions, defined as puncta, between ER and PM (Luik et al. 2006; Wu et al. 2006; Zhang et al. 2005). In this mechanism, a movement of the STIM1bearing ER membranes toward the surface membrane is required for obtaining a direct close opposition of $\mathrm{ER} \mathrm{Ca}^{2+}$ stores and PM containing ORAI1. As in a feedback loop, $\mathrm{Ca}^{2+}$ entry via STIM1-activated ORAI1 channels is used to then replenish depleted $\mathrm{ER} \mathrm{Ca}^{2+}$ stores, which was the initial signal for its activation.

\section{$\mathrm{Ca}^{2+}$ handling and SOCE in skeletal muscle}

In muscle, excitation contraction (EC) coupling, the mechanism linking the depolarization of PM to SR $\mathrm{Ca}^{2+}$ release, has evolved into different mechanisms: $\mathrm{Ca}^{2+}$-induced $\mathrm{Ca}^{2+}$ release (CICR), which uses external $\mathrm{Ca}^{2+}$ to induce release from internal stores in cardiac and smooth muscle (Fabiato 1983; Protasi et al. 1996; Sun et al. 1995); and mechanical coupling of skeletal muscle (Chandler et al. 1976; Rios et al. 1991; Schneider 1994). The term mechanical is used because the voltage-gated L-type $\mathrm{Ca}^{2+}$ channels of TTs, i.e. $\mathrm{CaV} 1.1$ also known as dihydropyridine receptors (DHPRs), are directly linked to the $\mathrm{Ca}^{2+}$ release channels of the SR, the ryanodine receptors type-1 (RYR1) (Block et al. 1988; Paolini et al. 2004; Protasi 2002). This direct link allows formation of DHPR-tetrads, in which 4 DHPRs associate to the four subunits of RYR1 (Block et al. 1988; Protasi et al. 1998).

As mechanical EC coupling is extracellular $\mathrm{Ca}^{2+}$ independent, the role of extracellular $\mathrm{Ca}^{2+}$ in skeletal muscle function and contractility has been neglected for many years. Evidence for a $\mathrm{Ca}^{2+}$ entry pathway independent from DHPRs was reported in the 90's (Gissel and Clausen 1999), before the first evidence of a $\mathrm{Ca}^{2+}$ entry pathway activated by depletion of $\mathrm{Ca}^{2+}$ in the SR was collected in mouse skeletal muscle fibers (Kurebayashi and Ogawa 2001). Later, the fact that muscle performance was reduced under conditions that inhibit SOCE supported the idea that SOCE contributes to contractility, especially during repetitive stimulation (Pan et al. 2014; Wei-Lapierre et al. 2013). Initially, it has been suggested that SOCE in muscle was mediated by coupling of $\mathrm{Ca}^{2+}$ release channels such as RYR or inositol-trisphosphate (INSP3) receptors in the SR membrane with transient receptor potential cation channels (TRPC) in the PM (Launikonis et al. 2003; Pan et al. 2002; Rosenberg et al. 2004). The discovery of SOCE being mediated by STIM1 and ORAI1 in nonexcitable cells (Feske et al. 2006; Roos et al. 2005) helped a few years later the identification of STIM1 and ORAI1 as the main players of SOCE also in skeletal muscle fibers (Lyfenko and Dirksen 2008). In support of this finding, the demonstration that SOCE is abolished in mice lacking STIM1 (Stiber et al. 2008) and in muscle fibers from dominant-negative and muscle-specific Orail- knockout mice (Carrell et al. 2016; Wei-Lapierre et al. 2013).

There is now general agreement regarding the fact that STIM1/ORAI1-dependant $\mathrm{Ca}^{2+}$-entry via SOCE increases force generation during prolonged stimulation (Boncompagni et al. 2017; Michelucci et al. 2019, 2020; Thornton et al. 2011). Indeed, removal of extracellular $\mathrm{Ca}^{2+}$ and addition of SOCE channel inhibitors (e.g. 2-APB, BTP2) reduced the ability of skeletal muscle to maintain 
contractile force during prolonged stimulation (Boncompagni et al. 2017). Furthermore, strong evidence has been collected in latest years also regarding the role that SOCE plays in long-term functions of muscle such as differentiation, development and growth. Indeed, both STIM1ORAI1 expression and SOCE activity are enhanced during differentiation of myotubes (Darbellay et al. 2009; Stiber et al. 2008), while their knockout reduces muscle mass in mice (Li et al. 2012; Wei-Lapierre et al. 2013).

It has been speculated that some features of STIM1ORAI1 interaction in skeletal fibers must be different from that occurring in non-excitable cells, mainly because of differences in the time-course of its activation. In non-muscle cells the process, from ER store depletion to ORAI1 channel activation, takes tens of seconds (Wu et al. 2006), while in skeletal muscle some authors have proposed that $\mathrm{Ca}^{2+}$ influx can be activated very rapidly $(<1 \mathrm{~s})$ following $\mathrm{Ca}^{2+}$ store depletion (Edwards et al. 2010; Launikonis and Rios 2007). This led some authors to conclude that the rapid activation of SOCE in muscle could be only explained by the presence of pre-formed SR-TT junctions promoting a preferential and fast access of STIM1 to ORAI1.

A few years later it has been suggested that muscle may contain two functionally distinct pools of STIM1: (a) one pool that mediates rapid SOCE activation located at the triad; and (b) a reserve pool at the I-band that would produce graded SOCE following store depletion (Stiber et al. 2008). Darbellay and colleagues discovered a Stiml splice variant highly expressed in skeletal muscle, Stiml-long, that could indeed account for rapid SOCE activation at the triad where the TTs contain ORAI1 (Darbellay et al. 2009, 2011).

\section{SOCE in muscle dysfunction and disease}

$\mathrm{As} \mathrm{Ca}^{2+}$ ions represent a versatile second messenger that controls a variety of cellular functions, dysregulation of $\mathrm{Ca}^{2+}$ homeostasis is often associated to dysfunction and skeletal muscle diseases (Avila-Medina et al. 2018; MacLennan 2000). Depressed or accelerated SOCE has been associated to several distinct forms of muscle dysfunction, i.e. weakness in aging (Brotto 2011; Pan et al. 2014; Thornton et al. 2011), muscular dystrophy in $m d x$ mice (Zhao et al. 2012; Goonasekera et al. 2014; Onopiuk et al. 2015), and oversensitivity to heat in malignant hyperthermia (Yarotskyy and Dirksen 2012; Yarotskyy et al. 2013).

SOCE dysfunction can be directly caused by mutations in genes encoding for STIM1 and ORAI1, which can cause loss- or gain-of-function in the two proteins. Loss-of-function mutations in the genes encoding STIMI and ORAII have been linked to patients affected by a severe combined immunodeficiency, which is often combined with severe myopathies (Feske 2009; Feske et al. 2010; McCarl et al. 2009; Picard et al. 2009). McCarl et al. 2009 and Lian et al.
2018 indeed reported loss-of-function mutations in ORAII causing type I predominance and atrophic (or completely missing) type II fibers, while loss-of-function mutations in STIM1 have been also associated to severe muscle hypotonia (Fuchs et al. 2012; Picard et al. 2009).

On the other hand, gain-of-function mutations in the same two genes have been linked to three different diseases: Stormorken and York Platelet syndromes (Bohm and Laporte 2018; Borsani et al. 2018; Lacruz and Feske 2015; Nesin et al. 2014; Markello et al. 2015; Misceo et al. 2014; Morin et al. 2020) and to a rare form of myopathy known as tubular aggregate myopathy or TAM (Bohm et al. 2013, 2014; Bulla et al. 2019; Endo et al. 2015; Okuma et al. 2016; Walter et al. 2015).

Tubular aggregates (TAs) are unusual membranous structures, which represent an important indicator of human myopathies, and that have been also found in aging mice, where they preferentially assemble in fast twitch fibers (Boncompagni et al. 2012a; Chevessier et al. 2005). It is generally accepted that TAs originate mostly from SR membranes, while TTs and mitochondria seems to be excluded (Boncompagni et al. 2012a; Chevessier et al. 2005; Salviati et al. 1985; Vielhaber et al. 2001). The clinical spectrum of TAM varies: from asymptomatic, to slowly progressive limb weakness, to muscle pain and cramping, to joint deformities in the arms and legs (Engel et al. 1970; Jain et al. 2008; Pierobon-Bormioli et al. 1985; Stormorken et al. 1985). A murine model harboring the most common TAM/Stormorken syndrome mutation in the Stiml gene (R304W) has been recently characterized and manifested a multi-systemic phenotype, but no formation of TAs was reported (Silva-Rojas et al. 2019).

Recently, also calsequestrin-1 (CASQ1), a protein that acts as the main $\mathrm{Ca}^{2+}$ buffer in the SR (MacLennan et al. 1983) and that plays a central role in skeletal EC coupling, has been proposed to modulate SOCE by a retrograde signal that inhibits STIM1 aggregation (Shin et al. 2003; Wang et al. 2015; Zhang et al. 2016). Three novel mutations in the CASQ1 gene have been identified in patients affected by TAM (Barone et al. 2017): Laporte and colleagues suggested that mutations in the $C A S Q 1$ gene impair its polymerization and cause TAM (Bohm et al. 2018).

\section{Calcium Entry Units, newly characterized intracellular SR/TT junctions that promote STIM1-ORAI1 colocalization and enhance Store-operated $\mathrm{Ca}^{2+}$ entry}

\section{Searching for SOCE-sites in muscle}

Different electron microscopy (EM) studies proposed ER-PM junctions that form following depletion of intracellular stores as the SOCE sites (Orci et al. 2009; Wu 
et al. 2006). Perni and colleagues using EM combined with freeze-fracture preparations studied the localization of both STIM1 and ORAI1 in HEK-293 cells: in this study overexpression of Stiml and/or Orail induced formation of stacks of ER cisternae joined together by electrondense small linkers, with ORAI1 clustered in specialized domains of the PM. It is worth emphasizing that overexpression of Stiml in this study induced the formation PM invaginations (structures similar to primitive TTs of muscle) associated to ER stacks (Perni et al. 2015).

Skeletal muscle fibers are the largest mammalian cells resulting from the fusion of progenitor cells (known as myoblasts) into myotubes. While myotubes grow in size, the nuclei that are initially placed approximately in the center of myotubes, move toward the periphery to leave space for the contractile, metabolic, and $\mathrm{Ca}^{2+}$ handling machineries (Engel and Franzini Armstrong 1994). When finally mature, adult skeletal fibers appear very densely packed with organelles that apparently occupy pre-determined positions: (a) myofibrils aligned transversally to create the striated appearance of skeletal fibers visible in histology; (b) most mitochondria placed at the I band in proximity of $\mathrm{Z}$ lines; (c) triads, the sites of excitation-contraction (EC) coupling, placed at the I-A band junction of sarcomeres, often closely associated to mitochondria (Bolanos et al. 2008; Boncompagni et al. 2009, 2020; Franzini-Armstrong and Boncompagni 2011; Rossi et al. 2009, 2011). Triads, also known as Calcium Release Units (CRUs), are sites where TTs (which carry the action potentials in the fiber interior) and the SR (that contains releasable $\mathrm{Ca}^{2+}$ ) come in close contact with each other. CRUs are the specialized intracellular junctions allowing the mechanical coupling between DHPRs, or CaV1.1 L-type $\mathrm{Ca}^{2+}$ channel, with the $\mathrm{SR} \mathrm{Ca}^{2+}$ release channels, the RYR1 (Franzini-Armstrong and Protasi 1997; Schneider and Chandler 1973; Schneider 1994).

Activation of SOCE requires an interaction between STIM1, the $\mathrm{Ca}^{2+}$ sensor of SR membranes, and ORAI1, a $\mathrm{Ca}^{2+}$ release activated channel (CRAC) placed in external membranes, either the PM of its invaginations, i.e. the TTs (Liou et al. 2005; Prakriya et al. 2006; Roos et al. 2005; Vig et al. 2006; Wu et al. 2006; Yeromin et al. 2006; Zhang et al. 2005). As detailed in "Store-operated $\mathrm{Ca}^{2+}$ entry in skeletal muscle function and disease", it has been suggested that the rapid kinetics of SOCE activation in skeletal muscle (Edwards et al. 2010; Launikonis and Rios 2007; Launikonis et al. 2009) would require a preformed site of interaction between STIM1 and ORAI1 (Dirksen 2009). As in triad junctions TTs and SR are already associated to each other to mediate EC coupling, this site would in principle represent the perfect location for SOCE (Dirksen 2009; Launikonis and Rios 2007; Launikonis et al. 2009). Indeed, in triads TTs (external membranes which may contain ORAI1) and the SR (which contains STIM1) are already in close proximity and could in principle allow a prompt and direct molecular interaction between STIM1 and ORAI1 during the rapid SOCE activation in muscle.

This hypothesis, though, was not supported by direct experimental evidence and it should be acknowledged that some peculiar features of triad junctions may represent a limit for proper STIM1-ORAI1 interaction. The junctional SR-TT gap at the triad is a quite crowded space filled by the large cytoplasmic domains of RYRs (known as feet). In the triadic junction RYR-feet are in direct contact with one another, corner-to-corner, forming regular arrays (Ferguson et al. 1984; Paolini et al. 2004), and are mechanically coupled with DHPR-tetrads that are placed across the junctional gap in the TT membrane (Protasi et al. 1998; Protasi 2002). Additionally, many other proteins such as junctophilins, FKBP12, triadin, junctin, mitsugumin, STAC3, etc., modulate EC coupling and participate in the assembly and maintenance of the triad junction (Al-Qusairi and Laporte 2011; Boncompagni et al. 2012b; Ito et al. 2001; Nelson et al. 2013; Protasi et al. 1997; Tang et al. 2004). Hence, the complex macromolecular machinery contained in triads may result in only limited opportunity for movement of STIM1 oligomers to recruit ORAI1 channels that are located across the triadic gap in the junctional portion of TTs.

The issue raised above suggests the possibility that SOCE may occur at sites different from the triads. Recently published manuscripts, discussed in the following sections of this Chapter, suggest that the most likely site for SOCE may indeed not be the triad (Boncompagni et al. 2017, 2018; Michelucci et al. 2018, 2020).

\section{Remodeling of internal membranes and increased STIM1-ORAI1 colocalization induced by exercise}

Recent evidence indicates that one hour of incremental running on a treadmill determines a striking remodelling of internal membranes of the sarcomere in EDL muscle of mice (Fig. 1). The SR at the I band in control conditions forms a complex network that in longitudinal sections appear as vesicles and convoluted tubes packed in multiple layers between $\mathrm{Z}$ line and triad (Fig. 1a). Following exercise, though, these membranes may rearrange in stacks of flat and parallel cisternae, which are formed by 2 or more elements (Fig. 1b). In these SR stacks the individual cisternae appear bridged together by several small electron dense strands which span a junctional gap of about $8 \mathrm{~nm}$ (Boncompagni et al. 2017). These stacks resemble those that form in non-muscle cells overexpressing Stiml (Orci et al. 2009; Perni et al. 2015), and present features that allow to clearly distinguish them from triadic junctions (CRUs). First, the electron densities in triads, i.e. RYR-feet, are significantly larger in size than the strands in SR stacks: indeed RYR-feet require a junctional 


\section{Control}

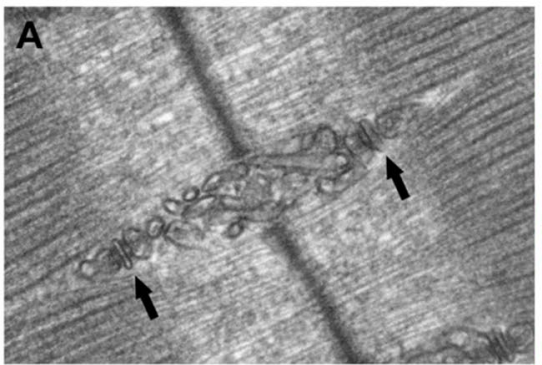

Exercised

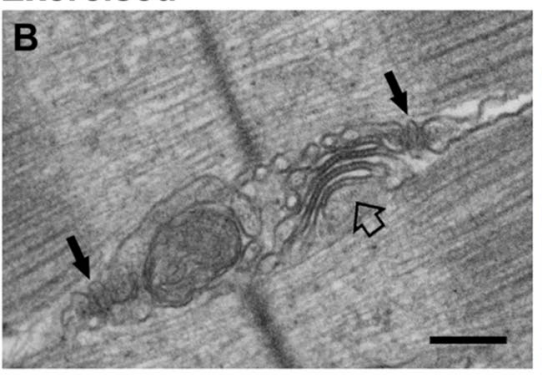

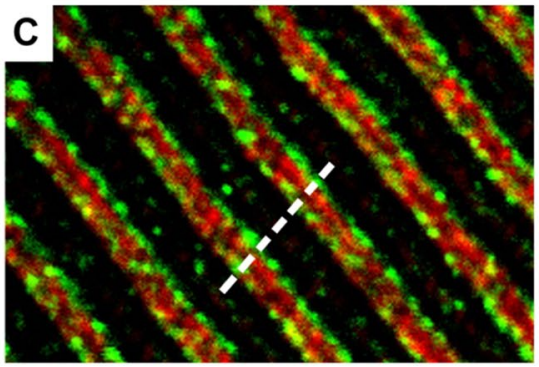

E
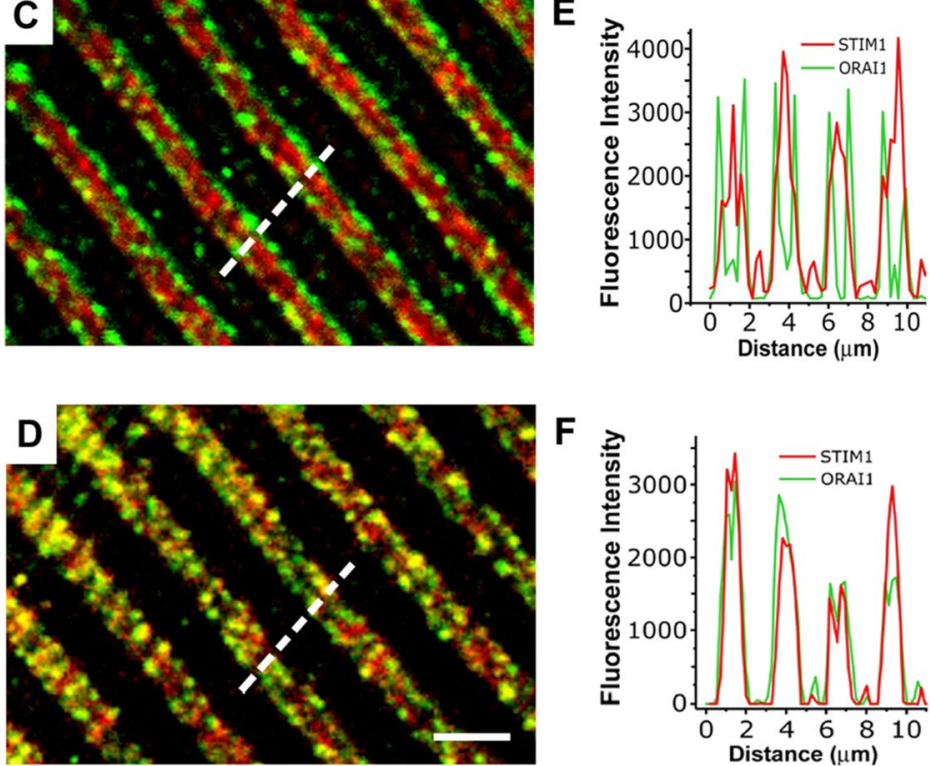

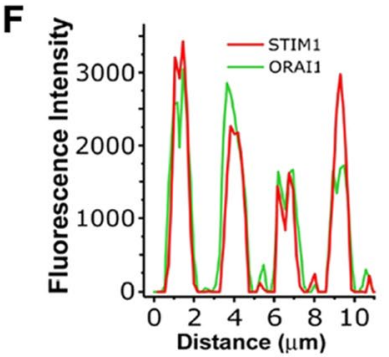

Fig. 1 Exercise results in remodeling of internal membranes and increase in STIM1-ORAI1 colocalization. a and b Representative electron-micrographs obtained from EDL fibers from control (panel a) mice and exercised (panel b) mice: black arrows point to triads, while the empty arrow in B points to an SR stack at the I band. $\mathbf{c}$ and d Representative immunofluorescence images obtained from EDL fibers double-labeled for STIM1-ORAI1 from control (panel c) mice and exercised (panel d) mice. e and f Fluorescence intensity profile obtained along $5 \mu \mathrm{m}$ distance (see dashed line) in fibers from control mice and exercised mice. In control conditions (c and e) STIM1 is preferentially localized at the I band of sarcomeres, with a low degree of colocalization with ORAI1, while following exercise (d and f) their degree of colocalization is significantly increased. Scale bar: $0.2 \mu \mathrm{m}(\mathbf{a}, \mathbf{b}) ; 2 \mu \mathrm{m}(\mathbf{c}, \mathbf{d})$ space of about $12 \mathrm{~nm}$ to be allocated. Second, the cisternae in SR stacks do not contain the electron-dense polymer (representing CASQ) that is present in the terminal cisternae of triads (Boncompagni et al. 2012b; Franzini-Armstrong and Protasi 1997; Franzini-Armstrong et al. 1987).

Boncompagni and colleagues (Boncompagni et al. 2017, 2018) showed that the remodeling of membranes at the I band during exercise, not only involved the SR, but also the TTs which extended from triads into the I band towards the stacks of SR. Finally, immunolabeling for confocal microscopy (and immonogold for EM) pointed to increased colocalization between STIM1 and ORAI1 following treadmill running (Fig. 1c-f). Before exercise STIM1 appeared preferentially localized at the I band of sarcomere (Fig. 1c and e), with a low degree of colocalization with (both RYR1 and) ORAI1, which display an almost exclusive triadic positioning. On the other hand, following exercise the degree of colocalization between the two proteins was significantly increased (Fig. 1d and $f$ ) due to migration of part of the ORAI1 signal toward the I band containing STIM1. The easier explanation for this result would be that the relocation of ORAI1 may be the direct consequence of the TT elongation into the I band. One additional interpretation of these findings would be that the interaction between STIM1 and ORAI1 (required for SOCE activation) would be reduced in control conditions due to low degree of colocalization, while it should be facilitated and augmented following exercise.

\section{Exercise increases resistance to fatigue and ORAI1-dependent $\mathrm{Ca}^{2+}$ entry}

Structural remodeling of intracellular membranes following exercise was accompanied by significant changes in the functional output of EDL muscles.

1. Extensor digitorum longus (EDL) muscles from preexercised animals were more resistant to fatigue than control muscles during repetitive stimulation in presence of $2.5 \mathrm{mM}$ external $\mathrm{Ca}^{2+}$, but this augmented fatigue resistance was abolished in condition that prevented $\mathrm{Ca}^{2+}$ entry, i.e. $\mathrm{Ca}^{2+}$ free extracellular solution, or presence of SOCE blockers (Boncompagni et al. 2017) such as BTP-2 and 2-APB (Bootman et al. 2002; Zitt et al. 2004).

2. The functional implications of the exercise-induced remodeling of SR and elongation of TT were dissected more in depth in Michelucci et al. 2019 studying single fibers isolated from flexor digitorum brevis (FDB) using $\mathrm{Mn}^{2+}$ quenching of Fura-2 fluorescence, the state-of-theart technique to measure entry of divalent cations from 
the extracellular space. Results of those experiments pointed to a significantly augmented entry of $\mathrm{Mn}^{2+}$ both following depletion of intracellular stores (+depletion) and even in absence of depletion (- depletion) in FDB fibers of pre-exercised animals compared to controls. These findings were complemented by the demonstration that this $\mathrm{Ca}^{2+}$ entry pathway was dependent on presence of ORAI1, as the exercise-induced adaptations were absent in two different models of Orail-knockout: (a) dominant-negative Orail transgenic mice (WeiLapierre et al. 2013) and (b) tamoxifen-inducible Orail knockout mice (Carrell et al. 2016). Finally, Michelucci et al. 2019 also determined how the $\mathrm{Ca}^{2+}$ entry induced by the remodeling of SR and TT membranes at the I band increased $\mathrm{Ca}^{2+}$ transients, resting $\mathrm{Ca}^{2+}$, and contractile force during repetitive stimulation.

In conclusion, the increased rate of $\mathrm{Mn}^{2+}$ quench in $\mathrm{FDB}$ fibers containing the SR-TT remodeling suggests that the new junctions that form during exercise function as $\mathrm{Ca}^{2+}$ Entry Units (CEUs) to support SOCE during repetitive muscle activity. This conclusion is also reinforced by immunofluorescence and immunogold labeling in Boncompagni et al. 2017, pointing to increased colocalization of STIM1 and ORAI1 following exercise.

\section{$\mathrm{Ca}^{2+}$ Entry Units are constitutively assembled in mice lacking calsequestrin-1}

Calsequestrin is a high-capacity $\mathrm{Ca}^{2+}$-binding protein located in the lumen of the SR terminal cisternae (Campbell et al. 1983; Yano and Zarain-Herzberg 1994). There is a general consensus that calsequestrin is not only important for the SR ability to store $\mathrm{Ca}^{2+}$, but also for modulating $\mathrm{Ca}^{2+}$ release from RYRs (Beard et al. 2002, 2005; Ikemoto et al. 1989). Structural studies suggested that calsequestrin is indeed in the right location to control the activity of the $\mathrm{Ca}^{2+}$ release channels (Franzini-Armstrong et al. 1987; Saito et al. 1984). Recent evidence suggests that CASQ1 also modulates SOCE (Barone et al. 2017; Shin et al. 2003; Wang et al. 2015; Zhao et al. 2010).

Skeletal muscles from mice lacking calsequestrin-1 (Casq1-null) exhibit reduced SR $\mathrm{Ca}^{2+}$ content and undergo rapid and deep SR $\mathrm{Ca}^{2+}$ depletion (the key signal to activate SOCE) during sustained, high-frequency stimulation (Paolini et al. 2007; Canato et al. 2010). In the first paper describing the structure of the EC coupling system of these knockout mice (Paolini et al. 2007), the presence of SR stacks was overseen. Later the presence of SR stacks was reported in fibers from mice lacking CASQ1 and 2 (Boncompagni et al. 2012a; see "Exercise-like sarcotubular remodeling is also found in animal models with defective $\mathrm{Ca}^{2+}$ handling"). Very recently Michelucci and colleagues reported that: (a) in skeletal muscle from mice lacking calsequestrin-1, CEUs are constitutively assembled in EDL and FDB muscles (Michelucci et al. 2020; an SR stack in Casq1-null muscle is shown in Fig. 2a); (b) the presence of CEUs correlated with enhanced constitutive- and store-operated $\mathrm{Ca}^{2+}$ entry; and (c) the recovery of $\mathrm{Ca}^{2+}$ ions via SOCE served to promote enhanced maintenance of peak $\mathrm{Ca}^{2+}$ transient amplitude, and increased maintenance of contractile force during repetitive, high-frequency stimulation.

\section{T-tubule plasticity controls the assembly of functional Calcium Entry Units (CEUs)}

Data in Michelucci et al. 2019 indicate that T-tubules elongation into the I band during exercise is required for increased $\mathrm{Mn}^{2+}$ quench. Indeed, this work contains a timecourse study in which assembly and disassembly of CEUs was studied $<1 \mathrm{~h}, 6 \mathrm{~h}$ and $24 \mathrm{~h}$ after a single bout of treadmill running: a) TTs retracts from SR stacks within $6 \mathrm{~h}$ following exercise; b) SR stacks disappear within $24 \mathrm{~h}$. The fact that SOCE function is enhanced when TTs extension
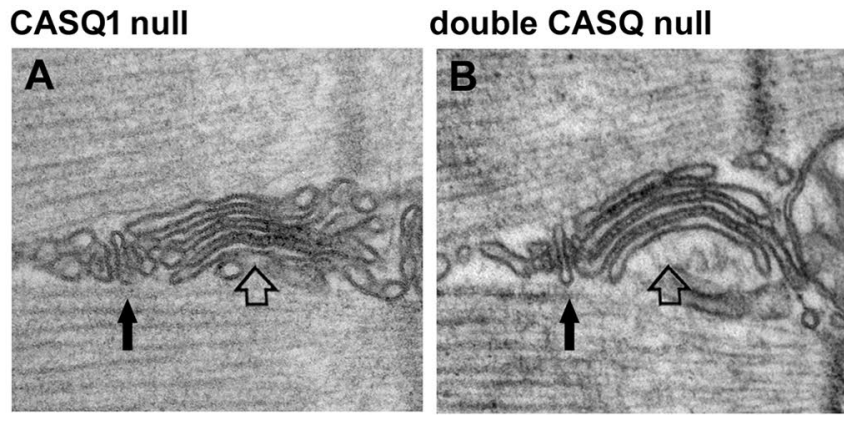

Fig. 2 Exercise-like SR remodeling is also found in animal models with defective $\mathrm{Ca}^{2+}$ handling. Structures virtually identical to SR stacks formed during exercise (pointed by empty arrows) are often found also in mouse models carrying ablation of proteins involved in
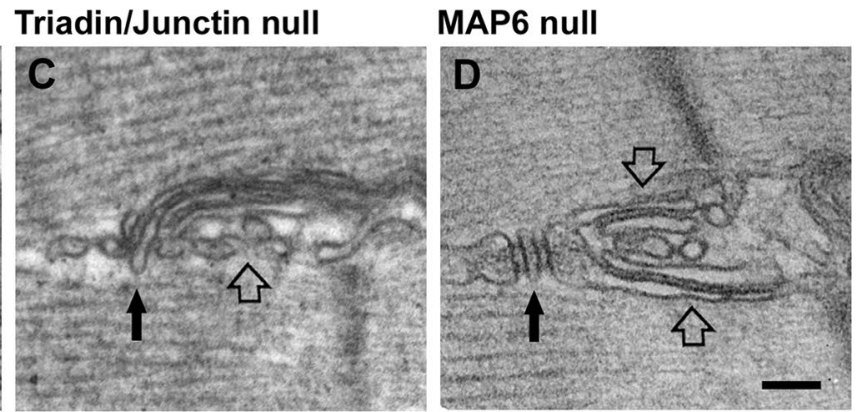

$\mathrm{Ca}^{2+}$ handling at the triad (pointed by black arrows), such as calsequestrin, triadin and junctin, and in Map6 knockout mice. Scale bar: $0.1 \mu \mathrm{m}$ 
and contacts with SR stacks are increased, but returns to control levels once TTs retract from the I band, points to a central role of TTs in the assembly of functional CEUs. The mechanism underlying TT elongation and the reason of a higher plasticity of TT vs. SR stacks remain elusive and deserve further investigation (see "Open Questions and Future Directions" for more detail).

\section{Exercise-like sarcotubular remodeling is also found in animal models with defective $\mathrm{Ca}^{2+}$ handling}

The SR, the organelle with the major impact on $\mathrm{Ca}^{2+}$ homeostasis of skeletal muscle, is a convoluted compartment composed by tubules and cisternae, which forms a continuous network surrounding each myofibril (Rossi and Dirksen 2006). It is essentially composed of two continuous domains: junctional and longitudinal SR. The junctional SR flanks a central T-tubule to form the triad, also known as CRU, a structure deputed to $\mathrm{Ca}^{2+}$ accumulation and release during EC coupling thanks to the presence of CASQ and RYRs. The longitudinal SR, on the other hand, surrounds both $\mathrm{A}$ and $\mathrm{I}$ bands and it is important for $\mathrm{Ca}^{2+}$ re-uptake as it contains SERCA pumps (Flucher et al. 1993). Next to the I band, the longitudinal SR is formed by multiple layers (instead of a single layer as at the A band), possibly because at the I band more space is available as at rest contractile filaments are not overlapped. The proteins involved in the maturation of both longitudinal and junctional SR, and how these proteins are retained in different and specialized domains depending on their role/function, have been extensively reviewed (Rossi et al. 2008). Al-Qusairi and Laporte provided also additional insight about the role that proteins such as caveolin 3, amphiphysin 2, dysferlin, mitsugumins, junctophilins, etc. may play in T-tubule biogenesis, triad formation and/or maintenance, and their implication in muscle disorders (Al-Qusairi and Laporte 2011).

The longitudinal SR at the I band is the one that provides the membranes that undergo exercise-induced remodeling resulting in formation of SR stacks (see "Calcium Entry Units, newly characterized intracellular SR/TT junctions that promote STIM1-ORAI1 colocalization and enhance Storeoperated $\mathrm{Ca}^{2+}$ entry"). Plasticity of the sarcotubular system during differentiation and maturation of muscle fibers has been studied (Flucher et al. 1993). Modification of EC coupling membranes during aging and disease have been also reported in muscle from humans and mice (Boncompagni et al. 2006; Chevessier et al. 2004; Lee and Noguchi 2016; Pietrangelo et al. 2015). Less is known, though, about the sarcotubular plasticity in healthy adult muscle. Reviewing the existing literature, though, we realized that SR stacks virtually identical to those formed during exercise in adult mice (see "Calcium Entry Units, newly characterized intracellular SR/TT junctions that promote STIM1-ORAI1 colocalization and enhance Store-operated $\mathrm{Ca}^{2+}$ entry") were also noted in mouse models carrying either ablation of proteins involved in EC coupling and in a mouse with a null mutation to a microtubule associate protein (Fig. 2). What follows are brief descriptions of those studies:

\section{Ko et al. (2011)}

Junctophilins (JPs) are a family of proteins that contribute to the formation of junctional membrane complexes linking the PM (or its invaginations) with the ER and SR in non-excitable and excitable cells (Takeshima et al. 2000). JPs provides a structural foundation for functional crosstalk between the cell surface and intracellular stores. JPs are the likely candidates for the docking of the junctional SR to TT in triads of skeletal muscle (Ito et al. 2001; Takeshima et al. 2000). Hirata and colleagues in 2006 reported that knockdown of $J p 1$ and $J p 2$ (two different isoforms) caused a drastic reduction on SOCE activation in $\mathrm{C} 2 \mathrm{C} 12$ cells (Hirata et al. 2006). The same group of authors a few year later, reported the effect of inducing transient knockdown of Jps in adult muscle fibers, concluding that reduced expression of JP1 and JP2 leads to abnormal junctional membrane structure and defective $\mathrm{Ca}^{2+}$ signaling (reduced $\mathrm{SR} \mathrm{Ca}{ }^{2+}$ store and defective operation of SOCE). In the EM images published by Ko et al. 2011, SR stacks virtually identical to those formed during exercise in Boncompagni et al. 2017 are clearly visible. In this paper SR stacks were described as irregular triad junctions.

\section{Boncompagni et al. (2012a)}

Two Casq isoforms are expressed during skeletal muscle development: a skeletal and a cardiac isoform, respectively Casq1 and Casq2 (Fliegel et al. 1987; Scott et al. 1988). In slow muscle, the CASQ2 protein is the most abundant isoform in fetal and neonatal stages, whereas in adults it accounts for $25-50 \%$ of the total CASQ present (Damiani et al. 1990). In fast twitch fibers, CASQ2 disappears at twofour weeks post-natally in rodents (Sacchetto et al. 1993). In Boncompagni et al. 2012a the presence of SR stacks was reported in muscle fibers of 4-6 month old double Casq-null mice: in that paper no specific analysis of TTs (the second element required for the assembly of functional CEUs) was performed at the time. An SR stack in double Casq-null muscles in shown in Fig. 2b. Now we know that also EDL and FDB fibers of Casq1-null mice contain a great amount of CEUs and their presence correlates with enhanced SOCE (Michelucci et al. 2020; see also "Calcium Entry Units, newly characterized intracellular SR/TT junctions that 
promote STIM1-ORAI1 colocalization and enhance Storeoperated $\mathrm{Ca}^{2+}$ entry").

\section{Boncompagni et al. (2012b)}

Junctin and triadin (Caswell et al. 1991; Jones et al. 1995; Knudson et al. 1993) are two SR proteins believed to anchor CASQ to the terminal cisternae. Ultrastructural evidence for CASQ connection to SR membranes comes from the observations of strands linking the junctional SR membrane to the electron-dense content of terminal cisternae, in deepetch studies of vertebrates muscles (Franzini-Armstrong et al. 1987).

Triadin and junctin are also believed to modulate the activity of RYR $1 \mathrm{Ca}^{2+}$ release channels (Guo and Campbell 1995) facilitating the cross-communication between CASQ and RYR both in cardiac and skeletal muscle (Beard et al. 2002; Gyorke et al. 2004; Zhang et al. 1997). Several lines of evidence have suggested that triadin is also an important regulator of the myoplasmic $\mathrm{Ca}^{2+}$ homeostasis in skeletal muscle (Eltit et al. 2010; Fodor et al. 2008; Shen et al. 2007). Boncompagni et al. 2012b reported ho ablation of triadin and junctin caused evident alterations of the triad structure, i.e. reduction in size of terminal cisternae and loss of proper position of CASQ away from RYRs. Though, this work also reported that: (a) fibers from triadin-null and triadin/junctin double null muscles contain unusual accumulation of flat SR cisternae at the I band; and (b) SR cisternae are separated by small densities that are clearly different from feet. An SR stack in double triadin/junctin null fiber in shown in Fig. 2c. The SR cisternae displayed in Boncompagni et al. 2012b are virtually identical to the SR stack assembled in wild type (WT) adult mice following exercise (Boncompagni et al. 2017) and contain the small densities that bridge the gap between the different SR elements. The presence of SR stacks in triadin-null and double triadin/junctin null muscles was accompanied by functional alteration: $\mathrm{SR} \mathrm{Ca}^{2+}$ content, peak of $\mathrm{Ca}^{2+}$ transient, and rate of $\mathrm{Mn}^{2+}$ quench were all reduced.

\section{Valle et al. (2016)}

Valle and colleagues investigated the functional role of calsequestrin-2 (CASQ2) in slow- and fast-twitch skeletal muscles using knockout mice (Knollmann et al. 2006; Valle et al. 2016). CASQ2 is expressed throughout life in slowtwitch muscle fibers, but only in the first months of life in fast-twitch fibers. The authors claim that CASQ2 knockout results in increased expression of CASQ1, and no functional defects were detected in either EDL or Soleus muscles. Interestingly, the authors also report the presence of SR stacks which appear virtually identical to those that form in WT muscle following exercise in Boncompagni et al. 2017.

\section{Sebastien et al. (2018)}

Skeletal muscle fibers are characterized by an extraordinary internal organization, which is at the basis of their efficient muscle contraction. One important player in this intracellular organization, achieved during differentiation and maturation of adult fibers, is the microtubule network (Khairallah et al. 2012; Oddoux et al. 2013; Prins et al. 2009; Sebastien et al. 2018; Sparrow and Schock 2009). The microtubule network is dynamic and is regulated by many microtubule-associated proteins (MAPs). Sébastien and colleagues studied the role of the MAP6 protein in skeletal muscle organization and function using a Map6 knockout mouse. Map6 isoforms are known to stabilize microtubules in vitro against different challenges (Bosc et al. 1996; Denarier et al. 1998; Margolis et al. 1990). Map6 deletion in mice affected microtubule organization and determined SR structural abnormalities, identified by EM, which include defects in triads and formation of extensive stacks of SR flat cisternae, again resembling those forming in muscle of WT type mice following treadmill exercise (Boncompagni et al. 2017). An SR stack in a Map6 knockout fiber in shown in Fig. 2d. Structural modifications in Map6 knockout fibers were associated to defective EC coupling, i.e. reduced $\mathrm{Ca}^{2+}$ release causing reduced force output. No direct measurements of SOCE were performed in this study.

\section{Open Questions and Future Directions}

The role of extracellular $\mathrm{Ca}^{2+}$ in skeletal muscle has been neglected for many years, possibly due to fact that EC coupling in skeletal muscle is mechanical and independent on $\mathrm{Ca}^{2+}$ entry (Brum et al. 1987; Brum and Rios 1987; Schneider and Chandler 1973; Schneider 1994). Though, over the past two decades the importance of $\mathrm{Ca}^{2+}$ entry for muscle function has gained renewed attention. On one side SOCE, the $\mathrm{Ca}^{2+}$ entry pathway extensively discussed in this manuscript and many reviews (Avila-Medina et al. 2018; Lopez et al. 2020; Michelucci et al. 2019; Ong et al. 2019), is activated by a decrease of $\mathrm{Ca}^{2+}$ in SR stores, i.e. depletion (Lyfenko and Dirksen 2008). On the other side, a pathway known as excitation-coupled $\mathrm{Ca}^{2+}$ entry (ECCE), independent of SR store depletion, also received considerable attention in the first decade of this millennium. ECCE is based on a retrograde signal from RYR1 to CaV1.1, the two main players in EC coupling, which activates a slow $\mathrm{Ca}^{2+}$ entry pathway, not required for EC coupling itself (Cherednichenko et al. 2004, 2008; Hurne et al. 2005; Yang et al. 2007).

The exercise-induced remodeling of the sarcotubular system in CEUs containing pre-localized STIM1 and ORAI1 which enhance constitutive and store-operated $\mathrm{Ca}^{2+}$ entry, 
is bringing new light upon the short-term plasticity of skeletal muscle fibers to external demands, in this case exercise. However, several important issues remain un-answered.

\section{The basic mechanism that initiates/promotes assembly of SR stacks and CEUs remains elusive}

SOCE is activated by depletion of intracellular stores, a signal that leads to oligomerization of STIM1 and recruitment/ activation of ORAI1 and allows $\mathrm{Ca}^{2+}$ entry (Luik et al. 2006; Wu et al. 2006; Zhang et al. 2005). However, the mechanism underlying the morphological changes in SR/TT membranes which results in assembly of CEUs and increased STIM1ORAI1 colocalization in muscle fibers requires further investigation. The collection of papers discussed in "Exercise-like sarcotubular remodeling is also found in animal models with defective $\mathrm{Ca}^{2+}$ handling" suggests a possible common mechanism leading to assembly of SR stacks (i.e. reduced amount of $\mathrm{Ca}^{2+}$ stored in the SR, with consequent depletion). Unfortunately, in those papers a detailed analysis of TTs, the second element required for the assembly of functional CEUs, is missing. Hence, a final conclusion about the presence of fully assembled CEUs cannot be drawn. See Other Unresolved Issues (Is assembly of SR stacks in different mouse models underlined by a common mechanism?) for additional detail. To understand more about the molecular mechanisms underlying membrane remodeling future efforts should be focused in studying the role that proteins known to be involved in TT biogenesis and membrane-bending, such as bridging integrator-1 (BIN1) also known as amphiphysin-II, caveolin-3 (CAV3), myotubularin-1 (MTM1), junctophilins (JPs) (Al-Qusairi and Laporte 2011; Dowling et al. 2009; Lee et al. 2002; Takeshima et al. 2015), etc., may play in this process.

\section{The role that changes in intracellular micro-environment may play in membrane remodeling has not been explored}

It is well known that during exercise several intracellular parameters change in muscle fibers (Allen 2004; Allen et al. 2008a, b; Allen and Trajanovska 2012; Lamb 2002, Lamb 2009; Lamb and Westerblad 2011; Westerblad and Allen 2011):

- reduction in $\mathrm{pH}$, due to production of carbon dioxide during aerobic metabolism and to glycolysis that may produce excessive pyruvate and accumulation of lactic acid.

- Transient accumulation of reactive species of oxygen and nitrogen (ROS and RNS), now widely recognized as signaling molecules in muscle function.
- Decrease in ATP/ADP ratio and increase in levels of inorganic phosphate, whose concentration can increase rapidly during intense fatigue.

- Increase in temperature, due to generation of heat during aerobic metabolism and break down of ATP.

- Reduction in partial pressure of oxygen (hypoxia), due to increased $\mathrm{O}_{2}$ consumption during aerobic ATP production.

- Repetitive shortening and relaxation of contractile elements, which is sensed by mechano-sensors in contractile filaments and cytoskeleton (Piazzesi et al. 2018; Ward et al. 2014).

Interestingly, STIM1 has been proposed to be a multipurpose stress transducer activated by diverse stimuli, beside $\mathrm{Ca}^{2+}$ store depletion (Soboloff et al. 2012): (a) ROS were shown to induce STIM1 aggregation, translocation to ER-PM junctions and activation of ORAI1 channels without store depletion (Hawkins et al. 2010); (b) increased temperature from $37{ }^{\circ} \mathrm{C}$ to $41{ }^{\circ} \mathrm{C}$ was shown to trigger STIM1 activation independently of $\mathrm{Ca}^{2+}$ store depletion (Mancarella et al. 2011a; Xiao et al. 2011); (c) hypoxic stress and decreased ATP levels cause $\mathrm{Ca}^{2+}$ store depletion and activation of STIM1 proteins, even if coupling to ORAI1 channels seems prevented in this case (Mancarella et al. 2011b).

In view of the above, it is possible that STIM1 may act as a sensor for other stimuli, such as $\mathrm{pH}$, ROS, temperature and/or mechanical modification of membrane compartments.

\section{How mutation in STIM1, ORAI1, and CASQ1 genes (and dysfunctional SOCE in aging) lead to the formation of tubular aggregates is not clear}

Tubular aggregates (Tas), that preferentially assemble in fast twitch fibers (Engel et al. 1970), are accumulation of ordered SR tubes, often or regular size, which represent an important indicator of human muscle disorders, including TA myopathy (TAM). TAM begins in childhood and worsen over time with leg muscles most often affected. Affected individuals may have an unusual walking style (gait) or difficulty running, climbing stairs, or getting up from a squatting position. TAM has been linked to mutations is STIM1 and ORAI1 genes (Bohm et al. 2013, 2014; Nesin et al. 2014). However, the mechanism that from mutations in those proteins leads to assembly of TAs is not understood. Bohm and colleagues suggested that mutations in STIMI can induce its constitutive clustering, and that constitutively active STIM1 seems the major cause of a steadily elevated myoplasmic $\mathrm{Ca}^{2+}$ (Bohm et al. 2013). TAM may also result in STIM1independent activation of CRAC channels due to dominant mutations in ORAI1 (Nesin et al. 2014) and to suppression of the slow $\mathrm{Ca}^{2+}$-dependent inactivation of the CRAC channel (Endo et al. 2015). 
Recently, TAs were also found in patients with missense mutations in the CASQ1 gene. CASQ1 mutants showed reduced ability to store $\mathrm{Ca}^{2+}$ and a reduced inhibitory effect on SOCE (Barone et al. 2017). Also Bohm and colleagues identified CASQ1 as the third TAM gene (Bohm et al. 2018). Clinical, histological, genetic, and functional data supported the finding that $C A S Q 1$ mutations significantly impair its polymerization and depolymerization and result in aggregation of STIM1, thus providing a pathological link between STIM1- and CASQ1-related TAM (Bohm et al. 2018).

TAs, though, have been also found in muscles of male aging mice, almost exclusively in fast twitch fibers (Boncompagni et al. 2012a; Chevessier et al. 2004). Aging muscle is characterized by muscle weakness and depressed SOCE (Brotto 2011; Thornton et al. 2011; Zhao et al. 2008), but why TAs preferentially assemble in fast twitch fibers and in muscle of male mice during aging is unclear. One hypothesis is that accumulation of TAs in muscle fibers from male mice may be influenced by sex hormones (Baltgalvis et al. 2010) and possibly mediated by oxidative stress levels, which is usually higher in males than in females (Borras et al. 2003). Regarding the fiber type specificity: based on the demonstration that TAs represent sites of $\mathrm{Ca}^{2+}$ accumulation, probably slow twitch fibers do not develop TAs because of their greater amount of mitochondria which can help in buffering excess of $\mathrm{Ca}^{2+}$ (Chevessier et al. 2004). Other possibilities are that slow twitch fibers contain a lower amount of SR membranes (the membranes recruited to form TAs), and that they are better protected against cellular stress thanks to higher oxidative metabolism (Chevessier et al. 2004).

\section{Other unresolved issues}

1. CEUs increase in size/number during exercise also in slow twitch fibers? Presence of SR stacks, and exercise dependent assembly of CEUs, has been noticed and studied in EDL muscles, which are mainly constituted by fast twitch fibers. In EDL, CEUs are small and few in control animals, and increase in frequency and size following exercise. Will this be the case also in slow twitch fibers, or this increased assembly of SOCE-sites occurs only in fast twitch fibers, which cycle $\mathrm{Ca}^{2+}$ at a higher rate during EC coupling and re-uptake?

2. What about CEU assembly in long-term training? Boncompagni et al. 2017 and Michelucci et al. 2019 analyzed the effect of a single bout of treadmill running. However, what happens in long-term training has not been investigated. Studying the effects of training could disclose different scenarios: (a) constitutive presence of CEUs in muscle fibers from trained animals; (b) greater expression of Stiml and Orail that could mediate a faster and more effective response to exercise.
3. Do STIM1-short and STIM1-long play different roles in the exercise induced assembly of $\mathrm{Ca}^{2+}$ Entry Units? Stiber and colleagues proposed two functionally distinct pools of STIM1, one at the triad that mediates rapid SOCE and another one that serves as a reserve pool within the longitudinal SR at the I-band which could mediate recruitment of additional SOCE when needed (Stiber et al. 2008). Darbellay and colleagues discovered a Stiml splice variant highly expressed in skeletal muscle (Stim1-long) which should be involved in permanent clusters with ORAI1 at the triad (Darbellay et al. 2009, 2011). In this picture, graded recruitment of additional SOCE activity could be mediated by STIM1S, which indeed appears distributed throughout the longitudinal SR at the I band, in the perfect position to contribute to the assembly of CEUs during exercise.

4. Is assembly of SR stacks in different mouse models underlined by a common mechanism? Reviewing the papers reporting the presence of SR stacks in "Exercise-like sarcotubular remodeling is also found in animal models with defective $\mathrm{Ca}^{2+}$ handling" (Boncompagni et al. 2012a; Michelucci et al. 2020; Ko et al. 2011; Sebastien et al. 2018; Valle et al. 2016) it is tempting to hypothesize a common mechanism that underlies their formation, i.e. a reduced $\mathrm{SR} \mathrm{Ca}^{2+}$ store content which may predispose to easier depletions of the SR during repetitive muscle activity. However, this hypothesis is supported only by some, but not all, of these papers:

a. In Casq1-null and double Casq-null fibers, which contain a great amount of SR stacks (Boncompagni et al. 2012a; Michelucci et al. 2020), SR Ca ${ }^{2+}$ content is severely reduced, SR undergoes severe depletion when repetitively stimulated, and rate of $\mathrm{Mn}^{2+}$ quench is reduced (Paolini et al. 2007, 2011; Michelucci et al. 2020).

b. The presence of SR stacks in triadin-null and double triadin/junctin-null muscles was accompanied by reduced (i) $\mathrm{SR} \mathrm{Ca}{ }^{2+}$ content, (ii) peak of $\mathrm{Ca}^{2+}$ transient, and (iii) rate of $\mathrm{Mn}^{2+}$ quench (Boncompagni et al. 2012b).

c. Ko et al. 2011. showed that reduced expression of JP1 and JP2 leads to modification of SR structure (with formation of irregular triad junctions, in our eyes clearly SR stacks) accompanied by defective $\mathrm{Ca}^{2+}$ signaling (reduced $\mathrm{SR} \mathrm{Ca}^{2+}$ store and defective operation of SOCE).

d. On the other hand the following two papers do not contain experimental evidence to support the hypothesis of a common mechanism underlying formation of SR stacks:

e. In the paper of Valle and colleagues, in skeletal muscle fibers lacking CASQ2 no defects in SR $\mathrm{Ca}^{2+}$ content were reported (Valle et al. 2016). 
f. In Map6 knockout mice, the authors evaluated the SR content, but did not report a decrease in the amount of stored $\mathrm{Ca}^{2+}$ (only alteration in EC coupling, i.e. reduced $\mathrm{Ca}^{2+}$ release causing reduced force output, but no measurements of SOCE were performed) (Sebastien et al. 2018).

\section{Closing remarks}

\section{Summary}

The present manuscript describes recent findings regarding the remodeling of SR and TT membranes during exercise, which may have a significant impact on SOCE activity and skeletal muscle function:

1. exercise induces remodeling of intracellular membranes, resulting in assembly of new SR-TT junctions at the I band formed by SR stacks and extension of triadic TTs (Boncompagni et al. 2017, 2018);

2. these new SR-TT junctions promote STIM1-ORAI1 colocalization, and increase resistance of muscles during repetitive stimulation in presence of external $\mathrm{Ca}^{2+}$ (Boncompagni et al. 2017, 2018);

3. the presence of these junctions correlates with increased rate of $\mathrm{Mn}^{2+}$ quench and augmented amplitude of $\mathrm{Ca}^{2+}$ transients (Michelucci et al. 2019);

4. the elongation of TTs into the I band during muscle activity and its retraction following recovery controls the assembly of functional CEUs (Michelucci et al. 2019);

5. CEUs are constitutively assembled in Casq-null fibers, which are functionally defective, because of a significantly reduced SR $\mathrm{Ca}^{2+}$ content and tendency to undergo marked $\mathrm{SR} \mathrm{Ca}^{2+}$ depletion during high-frequency stimulation (Canato et al. 2010; Michelucci et al. 2020);

6. the presence of SR stacks have been reported previously in several other mouse models (junctophilin and triadin/ junctin-null mice, etc.) (Boncompagni et al. 2012a, b; Ko et al. 2011; Sebastien et al. 2018; Valle et al. 2016).

\section{Assembly of $\mathrm{Ca}^{2+}$ Entry Units and up-regulation of SOCE during exercise may represent an acute adaptation of muscle aiming to maintain proper intracellular $\mathrm{Ca}^{2+}$ levels}

The mechanisms that underlie muscle fatigue are very complex (Allen et al. 2008a). One of the contributing factors is the loss of $\mathrm{Ca}^{2+}$ in the extracellular space during repetitive muscle stimulation, as this would cause a reduction in releasable $\mathrm{Ca}^{2+}$ from the SR during EC coupling (Allen et al. 2008b). In this scenario the assembly during exercise of specific SR-TT junctions deputed to recover external $\mathrm{Ca}^{2+}$ (i.e. CEUs) may represent a positive adaptation of muscle, triggered by SR depletion, aiming to create a preferential pathway to recover extracellular $\mathrm{Ca}^{2+}$, replenish the SR, and possibly delay the onset of (or reduce) muscle fatigue. This hypothesis is supported by findings in Casql-null muscle, where the constitutive presence of CEUs in Casq1-null muscle is likely an adaptation of fibers to the chronic reduced amount of $\mathrm{Ca}^{2+}$ in the SR. With this in mind we could hypothesize that CEUs creates an open door for prompt access to extracellular $\mathrm{Ca}^{2+}$ supply when internal $\mathrm{Ca}^{2+}$ stores cannot provide sufficient ions from muscle function.

Acknowledgements Open access funding provided by Università degli Studi G. D’Annunzio Chieti Pescara within the CRUI-CARE Agreement.

Funding Funding was supported by Ministero dell'Istruzione, dell'Università e della Ricerca Grant No. PRIN \#2015ZZR4W3 and Fondazione Telethon Grant No. GGP19231.

Open Access This article is licensed under a Creative Commons Attribution 4.0 International License, which permits use, sharing, adaptation, distribution and reproduction in any medium or format, as long as you give appropriate credit to the original author(s) and the source, provide a link to the Creative Commons licence, and indicate if changes were made. The images or other third party material in this article are included in the article's Creative Commons licence, unless indicated otherwise in a credit line to the material. If material is not included in the article's Creative Commons licence and your intended use is not permitted by statutory regulation or exceeds the permitted use, you will need to obtain permission directly from the copyright holder. To view a copy of this licence, visit http://creativecommons.org/licenses/by/4.0/.

\section{References}

Al-Qusairi L, Laporte J (2011) T-tubule biogenesis and triad formation in skeletal muscle and implication in human diseases. Skelet Muscle 1(1):26.

Allen DG (2004) Skeletal muscle function: role of ionic changes in fatigue, damage and disease. Clin Exp Pharmacol Physiol 31(8):485-493. https://doi.org/10.1111/j.1440-1681.2004.04032 .X

Allen DG, Lamb GD, Westerblad H (2008a) Skeletal muscle fatigue: cellular mechanisms. Physiol Rev 88(1):287-332. https://doi. org/10.1152/physrev.00015.2007

Allen DG, Lamb GD, Westerblad H (2008b) Impaired calcium release during fatigue. J Appl Physiol 104(1):296-305. https://doi. org/10.1152/japplphysiol.00908.2007

Allen DG, Trajanovska S (2012) The multiple roles of phosphate in muscle fatigue. Front Physiol 3:463. https://doi.org/10.3389/ fphys.2012.00463

Avila-Medina J, Mayoral-Gonzalez I, Dominguez-Rodriguez A, Gallardo-Castillo I, Ribas J, Ordonez A, Rosado JA, Smani T (2018) The complex role of store operated calcium entry pathways and related proteins in the function of cardiac, skeletal and vascular smooth muscle cells. Front Physiol 9:257. https://doi. org/10.3389/fphys.2018.00257 
Baltgalvis KA, Greising SM, Warren GL, Lowe DA (2010) Estrogen regulates estrogen receptors and antioxidant gene expression in mouse skeletal muscle. PLoS One 5(4):e10164. https://doi. org/10.1371/journal.pone.0010164

Barone V, Del Re V, Gamberucci A, Polverino V, Galli L, Rossi D, Costanzi E, Toniolo L, Berti G, Malandrini A, Ricci G, Siciliano G, Vattemi G, Tomelleri G, Pierantozzi E, Spinozzi S, Volpi N, Fulceri R, Battistutta R, Reggiani C, Sorrentino V (2017) Identification and characterization of three novel mutations in the CASQ1 gene in four patients with tubular aggregate myopathy. Hum Mutat 38(12):1761-1773. https:// doi.org/10.1002/humu.23338

Beard NA, Sakowska MM, Dulhunty AF, Laver DR (2002) Calsequestrin is an inhibitor of skeletal muscle ryanodine receptor calcium release channels. Biophys J 82(1 Pt 1):310-320

Beard NA, Casarotto MG, Wei L, Varsanyi M, Laver DR, Dulhunty AF (2005) Regulation of ryanodine receptors by calsequestrin: effect of high luminal $\mathrm{Ca}^{2+}$ and phosphorylation. Biophys $\mathrm{J}$ 88(5):3444-3454. https://doi.org/10.1529/biophysj.104.05144 1

Block BA, Imagawa T, Campbell KP, Franzini-Armstrong C (1988) Structural evidence for direct interaction between the molecular components of the transverse tubule/sarcoplasmic reticulum junction in skeletal muscle. J Cell Biol 107(6 Pt 2):2587-2600. https://doi.org/10.1083/jcb.107.6.2587

Bohm J, Chevessier F, Maues De Paula A, Koch C, Attarian S, Feger C, Hantai D, Laforet P, Ghorab K, Vallat JM, Fardeau M, FigarellaBranger D, Pouget J, Romero NB, Koch M, Ebel C, Levy N, Krahn M, Eymard B, Bartoli M, Laporte J (2013) Constitutive activation of the calcium sensor STIM1 causes tubular-aggregate myopathy. Am J Hum Genet 92(2):271-278

Bohm J, Chevessier F, Koch C, Peche GA, Mora M, Morandi L, Pasanisi B, Moroni I, Tasca G, Fattori F, Ricci E, PenissonBesnier I, Nadaj-Pakleza A, Fardeau M, Joshi PR, Deschauer M, Romero NB, Eymard B, Laporte J (2014) Clinical, histological and genetic characterisation of patients with tubular aggregate myopathy caused by mutations in STIM1. J Med Genet 51(12):824-833

Bohm J, Laporte J (2018) Gain-of-function mutations in STIM1 and ORAI1 causing tubular aggregate myopathy and Stormorken syndrome. Cell Calcium 76:1-9

Bohm J, Lornage X, Chevessier F, Birck C, Zanotti S, Cudia P, Bulla M, Granger F, Bui MT, Sartori M, Schneider-Gold C, Malfatti E, Romero NB, Mora M, Laporte J (2018) CASQ1 mutations impair calsequestrin polymerization and cause tubular aggregate myopathy. Acta Neuropathol 135(1):149-151. https://doi.org/10.1007/ s00401-017-1775-x

Bolanos P, Guillen A, Rojas H, Boncompagni S, Caputo C (2008) The use of CalciumOrange-5N as a specific marker of mitochondrial $\mathrm{Ca}^{2+}$ in mouse skeletal muscle fibers. Pflugers Arch 455(4):721731. https://doi.org/10.1007/s00424-007-0312-5

Boncompagni S, d'Amelio L, Fulle S, Fano G, Protasi F (2006) Progressive disorganization of the excitation-contraction coupling apparatus in aging human skeletal muscle as revealed by electron microscopy: a possible role in the decline of muscle performance. J Gerontol A Biol Sci Med Sci 61(10):995-1008. https ://doi.org/10.1093/gerona/61.10.995

Boncompagni S, Rossi AE, Micaroni M, Beznoussenko GV, Polishchuk RS, Dirksen RT, Protasi F (2009) Mitochondria are linked to calcium stores in striated muscle by developmentally regulated tethering structures. Mol Biol Cell 20(3):1058-1067. https://doi. org/10.1091/mbc.e08-07-0783

Boncompagni S, Protasi F, Franzini-Armstrong C (2012a) Sequential stages in the age-dependent gradual formation and accumulation of tubular aggregates in fast twitch muscle fibers: SERCA and calsequestrin involvement. Age (Dordr) 34(1):27-41. https://doi. org/10.1007/s11357-011-9211-y

Boncompagni S, Thomas M, Lopez JR, Allen PD, Yuan Q, Kranias EG, Franzini-Armstrong C, Perez CF (2012b) Triadin/Junctin double null mouse reveals a differential role for Triadin and Junctin in anchoring CASQ to the jSR and regulating $\mathrm{Ca}^{(2+)}$ homeostasis. PLoS One 7(7):e39962. https://doi.org/10.1371/ journal.pone.0039962

Boncompagni S, Michelucci A, Pietrangelo L, Dirksen RT, Protasi F (2017) Exercise-dependent formation of new junctions that promote STIM1-Orai1 assembly in skeletal muscle. Sci Rep 7(1):14286. https://doi.org/10.1038/s41598-017-14134-0

Boncompagni S, Michelucci A, Pietrangelo L, Dirksen RT, Protasi F (2018) Addendum: Exercise-dependent formation of new junctions that promote STIM1-Orai1 assembly in skeletal muscle. Sci Rep 8(1):17463. https://doi.org/10.1038/s41598-018-33063-0

Boncompagni S, Pozzer D, Viscomi C, Ferreiro A, Zito E (2020) Physical and functional cross talk between endo-sarcoplasmic reticulum and mitochondria in skeletal muscle. Antioxid Redox Signal 32(12):873-883. https://doi.org/10.1089/ars.2019.7934

Bootman MD, Collins TJ, Mackenzie L, Roderick HL, Berridge MJ, Peppiatt CM (2002) 2-aminoethoxydiphenyl borate (2-APB) is a reliable blocker of store-operated $\mathrm{Ca}^{2+}$ entry but an inconsistent inhibitor of InsP3-induced $\mathrm{Ca}^{2+}$ release. FASEB J 16(10):11451150. https://doi.org/10.1096/fj.02-0037rev

Borras C, Sastre J, Garcia-Sala D, Lloret A, Pallardo FV, Vina J (2003) Mitochondria from females exhibit higher antioxidant gene expression and lower oxidative damage than males. Free Radic Biol Med 34(5):546-552

Borsani O, Piga D, Costa S, Govoni A, Magri F, Artoni A, Cinnante CM, Fagiolari G, Ciscato P, Moggio M, Bresolin N, Comi GP, Corti S (2018) Stormorken syndrome caused by a p.R304W STIM1 mutation: the first italian patient and a review of the literature. Front Neurol 9:859. https://doi.org/10.3389/fneur .2018.00859

Bosc C, Cronk JD, Pirollet F, Watterson DM, Haiech J, Job D, Margolis RL (1996) Cloning, expression, and properties of the microtubule-stabilizing protein STOP. Proc Natl Acad Sci U S A 93(5):2125-2130. https://doi.org/10.1073/pnas.93.5.2125

Brotto M (2011) Aging, sarcopenia and store-operated calcium entry: a common link? Cell Cycle 10(24):4201-4202

Brum G, Rios E (1987) Intramembrane charge movement in frog skeletal muscle fibres. Properties of charge 2. J Physiol 387:489-517. https://doi.org/10.1113/jphysiol.1987.sp016586

Brum G, Stefani E, Rios E (1987) Simultaneous measurements of $\mathrm{Ca}^{2+}$ currents and intracellular $\mathrm{Ca}^{2+}$ concentrations in single skeletal muscle fibers of the frog. Can J Physiol Pharmacol 65(4):681685. https://doi.org/10.1139/y87-112

Bulla M, Gyimesi G, Kim JH, Bhardwaj R, Hediger MA, Frieden M, Demaurex N (2019) ORAI1 channel gating and selectivity is differentially altered by natural mutations in the first or third transmembrane domain. J Physiol 597(2):561-582. https://doi. org/10.1113/JP277079

Campbell KP, MacLennan DH, Jorgensen AO (1983) Staining of the $\mathrm{Ca}^{2+}$-binding proteins, calsequestrin, calmodulin, troponin $\mathrm{C}$, and S-100, with the cationic carbocyanine dye "Stains-all". J Biol Chem 258(18):11267-11273

Canato M, Scorzeto M, Giacomello M, Protasi F, Reggiani C, Stienen GJ (2010) Massive alterations of sarcoplasmic reticulum free calcium in skeletal muscle fibers lacking calsequestrin revealed by a genetically encoded probe. Proc Natl Acad Sci U S A 107(51):22326-22331

Carrell EM, Coppola AR, McBride HJ, Dirksen RT (2016) Orai1 enhances muscle endurance by promoting fatigue-resistant type I fiber content but not through acute store-operated $\mathrm{Ca}^{2+}$ entry. FASEB J 30(12):4109-4119 
Caswell AH, Brandt NR, Brunschwig JP, Purkerson S (1991) Localization and partial characterization of the oligomeric disulfidelinked molecular weight 95,000 protein (triadin) which binds the ryanodine and dihydropyridine receptors in skeletal muscle triadic vesicles. Biochemistry 30(30):7507-7513. https://doi. org/10.1021/bi00244a020

Chandler WK, Rakowski RF, Schneider MF (1976) Effects of glycerol treatment and maintained depolarization on charge movement in skeletal muscle. J Physiol 254(2):285-316. https://doi. org/10.1113/jphysiol.1976.sp011233

Cherednichenko G, Hurne AM, Fessenden JD, Lee EH, Allen PD, Beam KG, Pessah IN (2004) Conformational activation of $\mathrm{Ca}^{2+}$ entry by depolarization of skeletal myotubes. Proc Natl Acad Sci U S A 101(44):15793-15798

Cherednichenko G, Ward CW, Feng W, Cabrales E, Michaelson L, Samso M, Lopez JR, Allen PD, Pessah IN (2008) Enhanced excitation-coupled calcium entry in myotubes expressing malignant hyperthermia mutation $\mathrm{R} 163 \mathrm{C}$ is attenuated by dantrolene. Mol Pharmacol 73(4):1203-1212

Chevessier F, Marty I, Paturneau-Jouas M, Hantai D, VerdiereSahuque M (2004) Tubular aggregates are from whole sarcoplasmic reticulum origin: alterations in calcium binding protein expression in mouse skeletal muscle during aging. Neuromuscul Disord 14(3):208-216. https://doi.org/10.1016/j. nmd.2003.11.007

Chevessier F, Bauche-Godard S, Leroy JP, Koenig J, PaturneauJouas M, Eymard B, Hantai D, Verdiere-Sahuque M (2005) The origin of tubular aggregates in human myopathies. J Pathol 207(3):313-323. https://doi.org/10.1002/path.1832

Courjaret R, Machaca K (2012) STIM and Orai in cellular proliferation and division. Front Biosci (Elite Ed) 4:331-341

Damiani E, Salvatori S, Margreth A (1990) Characterization of calsequestrin of avian skeletal muscle. J Muscle Res Cell Motil 11(1):48-55. https://doi.org/10.1007/BF01833325

Darbellay B, Arnaudeau S, Konig S, Jousset H, Bader C, Demaurex N, Bernheim L (2009) STIM1- and Orai1-dependent storeoperated calcium entry regulates human myoblast differentiation. J Biol Chem 284(8):5370-5380

Darbellay B, Arnaudeau S, Bader CR, Konig S, Bernheim L (2011) STIM1L is a new actin-binding splice variant involved in fast repetitive $\mathrm{Ca}^{2+}$ release. J Cell Biol 194(2):335-346

Denarier E, Fourest-Lieuvin A, Bosc C, Pirollet F, Chapel A, Margolis RL, Job D (1998) Nonneuronal isoforms of STOP protein are responsible for microtubule cold stability in mammalian fibroblasts. Proc Natl Acad Sci U S A 95(11):6055-6060. https ://doi.org/10.1073/pnas.95.11.6055

Dirksen RT (2009) Checking your SOCCs and feet: the molecular mechanisms of $\mathrm{Ca}^{2+}$ entry in skeletal muscle. J Physiol 587(Pt 13):3139-3147

Dowling JJ, Vreede AP, Low SE, Gibbs EM, Kuwada JY, Bonnemann CG, Feldman EL (2009) Loss of myotubularin function results in T-tubule disorganization in zebrafish and human myotubular myopathy. PLoS Genet 5(2):e1000372. https:// doi.org/10.1371/journal.pgen.1000372

Edwards JN, Friedrich O, Cully TR, von Wegner F, Murphy RM, Launikonis BS (2010) Upregulation of store-operated $\mathrm{Ca}^{2+}$ entry in dystrophic mdx mouse muscle. Am J Physiol Cell Physiol 299(1):C42-50

Eltit JM, Feng W, Lopez JR, Padilla IT, Pessah IN, Molinski TF, Fruen BR, Allen PD, Perez CF (2010) Ablation of skeletal muscle triadin impairs FKBP12/RyR1 channel interactions essential for maintaining resting cytoplasmic $\mathrm{Ca}^{2+}$. J Biol Chem 285(49):38453-38462

Endo Y, Noguchi S, Hara Y, Hayashi YK, Motomura K, Miyatake S, Murakami N, Tanaka S, Yamashita S, Kizu R, Bamba M, Goto Y, Matsumoto N, Nonaka I, Nishino I (2015) Dominant mutations in ORAI1 cause tubular aggregate myopathy with hypocalcemia via constitutive activation of store-operated $\mathrm{Ca}^{(2)(+)}$ channels. Hum Mol Genet 24(3):637-648

Engel AG, Franzini Armstrong C (1994) Myology, 2nd edn. McGraw-Hill, New York

Engel WK, Bishop DW, Cunningham GG (1970) Tubular aggregates in type II muscle fibers: ultrastructural and histochemical correlation. J Ultrastruct Res 31(5-6):507-525. https://doi. org/10.1016/s0022-5320(70)90166-8

Fabiato A (1983) Calcium-induced release of calcium from the cardiac sarcoplasmic reticulum. Am J Physiol 245(1):C1-14. https://doi. org/10.1152/ajpcell.1983.245.1.C1

Ferguson DG, Schwartz HW, Franzini-Armstrong C (1984) Subunit structure of junctional feet in triads of skeletal muscle: a freezedrying, rotary-shadowing study. J Cell Biol 99(5):1735-1742. https://doi.org/10.1083/jcb.99.5.1735

Feske S (2009) ORAI1 and STIM1 deficiency in human and mice: roles of store-operated $\mathrm{Ca}^{2+}$ entry in the immune system and beyond. Immunol Rev 231(1):189-209. https://doi.org/10.1111/j.1600065X.2009.00818.x

Feske S, Gwack Y, Prakriya M, Srikanth S, Puppel SH, Tanasa B, Hogan PG, Lewis RS, Daly M, Rao A (2006) A mutation in Orail causes immune deficiency by abrogating CRAC channel function. Nature 441(7090):179-185

Feske S, Picard C, Fischer A (2010) Immunodeficiency due to mutations in ORAI1 and STIM1. Clin Immunol 135(2):169-182

Fliegel L, Ohnishi M, Carpenter MR, Khanna VK, Reithmeier RA, MacLennan DH (1987) Amino acid sequence of rabbit fasttwitch skeletal muscle calsequestrin deduced from cDNA and peptide sequencing. Proc Natl Acad Sci U S A 84(5):1167-1171. https://doi.org/10.1073/pnas.84.5.1167

Flucher BE, Takekura H, Franzini-Armstrong C (1993) Development of the excitation-contraction coupling apparatus in skeletal muscle: association of sarcoplasmic reticulum and transverse tubules with myofibrils. Dev Biol 160(1):135-147

Fodor J, Gonczi M, Sztretye M, Dienes B, Olah T, Szabo L, Csoma E, Szentesi P, Szigeti GP, Marty I, Csernoch L (2008) Altered expression of triadin 95 causes parallel changes in localized $\mathrm{Ca}^{2+}$ release events and global $\mathrm{Ca}^{2+}$ signals in skeletal muscle cells in culture. J Physiol 586(23):5803-5818

Franzini-Armstrong C, Protasi F (1997) Ryanodine receptors of striated muscles: a complex channel capable of multiple interactions. Physiol Rev 77(3):699-729. https://doi.org/10.1152/physr ev.1997.77.3.699

Franzini-Armstrong C, Boncompagni S (2011) The evolution of the mitochondria-to-calcium release units relationship in vertebrate skeletal muscles. J Biomed Biotechnol 2011:830573. https://doi. org/10.1155/2011/830573

Franzini-Armstrong C, Kenney LJ, Varriano-Marston E (1987) The structure of calsequestrin in triads of vertebrate skeletal muscle: a deep-etch study. J Cell Biol 105(1):49-56. https://doi. org/10.1083/jcb.105.1.49

Fuchs S, Rensing-Ehl A, Speckmann C, Bengsch B, Schmitt-Graeff A, Bondzio I, Maul-Pavicic A, Bass T, Vraetz T, Strahm B, Ankermann T, Benson M, Caliebe A, Folster-Holst R, Kaiser P, Thimme R, Schamel WW, Schwarz K, Feske S, Ehl S (2012) Antiviral and regulatory $\mathrm{T}$ cell immunity in a patient with stromal interaction molecule 1 deficiency. J Immunol 188(3):1523-1533

Gissel H, Clausen T (1999) Excitation-induced $\mathrm{Ca}^{2+}$ uptake in rat skeletal muscle. Am J Physiol 276(2):R331-339. https://doi. org/10.1152/ajpregu.1999.276.2.R331

Goonasekera SA, Davis J, Kwong JQ, Accornero F, Wei-LaPierre L, Sargent MA, Dirksen RT, Molkentin JD (2014) Enhanced $\mathrm{Ca}(2)(+)$ influx from STIM1-Orai1 induces muscle pathology in mouse models of muscular dystrophy. Hum Mol Genet 23(14):3706-3715 
Guo W, Campbell KP (1995) Association of triadin with the ryanodine receptor and calsequestrin in the lumen of the sarcoplasmic reticulum. J Biol Chem 270(16):9027-9030. https://doi.org/10.1074/ jbc. 270.16 .9027

Gyorke I, Hester N, Jones LR, Gyorke S (2004) The role of calsequestrin, triadin, and junctin in conferring cardiac ryanodine receptor responsiveness to luminal calcium. Biophys J 86(4):2121-2128

Hawkins BJ, Irrinki KM, Mallilankaraman K, Lien YC, Wang Y, Bhanumathy CD, Subbiah R, Ritchie MF, Soboloff J, Baba Y, Kurosaki T, Joseph SK, Gill DL, Madesh M (2010) S-glutathionylation activates STIM1 and alters mitochondrial homeostasis. J Cell Biol 190(3):391-405

Hirata Y, Brotto M, Weisleder N, Chu Y, Lin P, Zhao X, Thornton A, Komazaki S, Takeshima H, Ma J, Pan Z (2006) Uncoupling store-operated $\mathrm{Ca}^{2+}$ entry and altered $\mathrm{Ca}^{2+}$ release from sarcoplasmic reticulum through silencing of junctophilin genes. Biophys J 90(12):4418-4427

Hoth M, Penner R (1992) Depletion of intracellular calcium stores activates a calcium current in mast cells. Nature 355(6358):353-356. https://doi.org/10.1038/355353a0

Hurne AM, O'Brien JJ, Wingrove D, Cherednichenko G, Allen PD, Beam KG, Pessah IN (2005) Ryanodine receptor type 1 (RyR1) mutations C4958S and C4961S reveal excitation-coupled calcium entry (ECCE) is independent of sarcoplasmic reticulum store depletion. J Biol Chem 280(44):36994-37004

Ikemoto N, Ronjat M, Meszaros LG, Koshita M (1989) Postulated role of calsequestrin in the regulation of calcium release from sarcoplasmic reticulum. Biochemistry 28(16):6764-6771. https ://doi.org/10.1021/bi00442a033

Ito K, Komazaki S, Sasamoto K, Yoshida M, Nishi M, Kitamura K, Takeshima H (2001) Deficiency of triad junction and contraction in mutant skeletal muscle lacking junctophilin type 1. J Cell Biol 154(5):1059-1067. https://doi.org/10.1083/jcb.200105040

Jain D, Sharma MC, Sarkar C, Suri V, Sharma SK, Singh S, Das TK (2008) Tubular aggregate myopathy: a rare form of myopathy. J Clin Neurosci 15(11):1222-1226

Jones LR, Zhang L, Sanborn K, Jorgensen AO, Kelley J (1995) Purification, primary structure, and immunological characterization of the 26-kDa calsequestrin binding protein (junctin) from cardiac junctional sarcoplasmic reticulum. J Biol Chem 270(51):3078730796. https://doi.org/10.1074/jbc.270.51.30787

Khairallah RJ, Shi G, Sbrana F, Prosser BL, Borroto C, Mazaitis MJ, Hoffman EP, Mahurkar A, Sachs F, Sun Y, Chen YW, Raiteri R, Lederer WJ, Dorsey SG, Ward CW (2012) Microtubules underlie dysfunction in duchenne muscular dystrophy. Sci Signal 5(236):ra56. https://doi.org/10.1126/scisignal.2002829

Knollmann BC, Chopra N, Hlaing T, Akin B, Yang T, Ettensohn K, Knollmann BE, Horton KD, Weissman NJ, Holinstat I, Zhang W, Roden DM, Jones LR, Franzini-Armstrong C, Pfeifer K (2006) Casq2 deletion causes sarcoplasmic reticulum volume increase, premature $\mathrm{Ca}^{2+}$ release, and catecholaminergic polymorphic ventricular tachycardia. J Clin Invest 116(9):2510-2520. https://doi. org/10.1172/JCI29128

Knudson CM, Stang KK, Moomaw CR, Slaughter CA, Campbell KP (1993) Primary structure and topological analysis of a skeletal muscle-specific junctional sarcoplasmic reticulum glycoprotein (triadin). J Biol Chem 268(17):12646-12654

Ko JK, Choi KH, Zhao X, Komazaki S, Pan Z, Weisleder N, Ma J (2011) A versatile single-plasmid system for tissue-specific and inducible control of gene expression in transgenic mice. FASEB J 25(8):2638-2649

Kurebayashi N, Ogawa Y (2001) Depletion of $\mathrm{Ca}^{2+}$ in the sarcoplasmic reticulum stimulates $\mathrm{Ca}^{2+}$ entry into mouse skeletal muscle fibres. J Physiol 533(Pt 1):185-199. https://doi.org/10.1111/ j.1469-7793.2001.0185b.x
Lacruz RS, Feske S (2015) Diseases caused by mutations in ORAI1 and STIM1. Ann N Y Acad Sci 1356:45-79. https://doi. org/10.1111/nyas. 12938

Lamb GD (2002) Excitation-contraction coupling and fatigue mechanisms in skeletal muscle: studies with mechanically skinned fibres. J Muscle Res Cell Motil 23(1):81-91. https://doi. org/10.1023/a:1019932730457

Lamb GD (2009) Mechanisms of excitation-contraction uncoupling relevant to activity-induced muscle fatigue. Appl Physiol Nutr Metab 34(3):368-372

Lamb GD, Westerblad H (2011) Acute effects of reactive oxygen and nitrogen species on the contractile function of skeletal muscle. J Physiol 589(Pt 9):2119-2127

Launikonis BS, Barnes M, Stephenson DG (2003) Identification of the coupling between skeletal muscle store-operated $\mathrm{Ca}^{2+}$ entry and the inositol trisphosphate receptor. Proc Natl Acad Sci U S A 100(5):2941-2944. https://doi.org/10.1073/pnas.05362 27100

Launikonis BS, Rios E (2007) Store-operated $\mathrm{Ca}^{2+}$ entry during intracellular $\mathrm{Ca}^{2+}$ release in mammalian skeletal muscle. J Physiol 583(Pt 1):81-97

Launikonis BS, Stephenson DG, Friedrich O (2009) Rapid $\mathrm{Ca}^{2+}$ flux through the transverse tubular membrane, activated by individual action potentials in mammalian skeletal muscle. J Physiol 587(Pt 10):2299-2312

Lee E, Marcucci M, Daniell L, Pypaert M, Weisz OA, Ochoa GC, Farsad K, Wenk MR, De Camilli P (2002) Amphiphysin 2 (Bin1) and T-tubule biogenesis in muscle. Science 297(5584):11931196. https://doi.org/10.1126/science. 1071362

Lee JM, Noguchi S (2016) Calcium dyshomeostasis in tubular aggregate myopathy. Int J Mol Sci 17(11):1952

Li T, Finch EA, Graham V, Zhang ZS, Ding JD, Burch J, Oh-hora M, Rosenberg P (2012) STIM1-Ca ${ }^{(2+)}$ signaling is required for the hypertrophic growth of skeletal muscle in mice. Mol Cell Biol 32(15):3009-3017

Lian J, Cuk M, Kahlfuss S, Kozhaya L, Vaeth M, Rieux-Laucat F, Picard C, Benson MJ, Jakovcevic Bilic K, Martinac I, Stathopulos P, Kacskovics I, Vraetz T, Speckmann C, Ehl S, Issekutz T, Unutmaz D, Feske S (2018) ORAI1 mutations abolishing storeoperated $\mathrm{Ca}^{(2+)}$ entry cause anhidrotic ectodermal dysplasia with immunodeficiency. J Allergy Clin Immunol 142(4):1297-1310

Liou J, Kim ML, Heo WD, Jones JT, Myers JW, Ferrell JE $\mathrm{Jr}$, Meyer T (2005) STIM is a $\mathrm{Ca}^{2+}$ sensor essential for $\mathrm{Ca}^{2+}$-store-depletion-triggered $\mathrm{Ca}^{2+}$ influx. Curr Biol 15(13):1235-1241. https://doi.org/10.1016/j.cub.2005.05.055

Lopez JJ, Jardin I, Albarran L, Sanchez-Collado J, Cantonero C, Salido GM, Smani T, Rosado JA (2020) Molecular basis and regulation of store-operated calcium entry. Adv Exp Med Biol 1131:445469. https://doi.org/10.1007/978-3-030-12457-1_17

Luik RM, Wu MM, Buchanan J, Lewis RS (2006) The elementary unit of store-operated $\mathrm{Ca}^{2+}$ entry: local activation of CRAC channels by STIM1 at ER-plasma membrane junctions. J Cell Biol 174(6):815-825

Lyfenko AD, Dirksen RT (2008) Differential dependence of storeoperated and excitation-coupled $\mathrm{Ca}^{2+}$ entry in skeletal muscle on STIM1 and Orai1. J Physiol 586(20):4815-4824

MacLennan D, Campbell K, Reithmeier R (1983) Calsequestrin. In: Cheung W (ed) Calcium and cell function, vol 4. Academic Press, New York, pp 151-173

MacLennan DH (2000) $\mathrm{Ca}^{2+}$ signalling and muscle disease. Eur J Biochem 267(17):5291-5297

Mancarella S, Wang Y, Gill DL (2011a) Signal transduction: STIM1 senses both $\mathrm{Ca}^{(2)+}$ and heat. Nat Chem Biol 7(6):344-345

Mancarella S, Wang Y, Deng X, Landesberg G, Scalia R, Panettieri RA, Mallilankaraman K, Tang XD, Madesh M, Gill DL (2011b) Hypoxia-induced acidosis uncouples the STIM-Orai calcium 
signaling complex. J Biol Chem 286(52):44788-44798. https:// doi.org/10.1074/jbc.M111.303081

Margolis RL, Rauch CT, Pirollet F, Job D (1990) Specific association of STOP protein with microtubules in vitro and with stable microtubules in mitotic spindles of cultured cells. EMBO J 9(12):4095-4102

Markello T, Chen D, Kwan JY, Horkayne-Szakaly I, Morrison A, Simakova O, Maric I, Lozier J, Cullinane AR, Kilo T, Meister L, Pakzad K, Bone W, Chainani S, Lee E, Links A, Boerkoel C, Fischer R, Toro C, White JG, Gahl WA, Gunay-Aygun M (2015) York platelet syndrome is a CRAC channelopathy due to gain-offunction mutations in STIM1. Mol Genet Metab 114(3):474-482. https://doi.org/10.1016/j.ymgme.2014.12.307

McCarl CA, Picard C, Khalil S, Kawasaki T, Rother J, Papolos A, Kutok J, Hivroz C, Ledeist F, Plogmann K, Ehl S, Notheis G, Albert MH, Belohradsky BH, Kirschner J, Rao A, Fischer A, Feske S (2009) ORAI1 deficiency and lack of store-operated $\mathrm{Ca}^{2+}$ entry cause immunodeficiency, myopathy, and ectodermal dysplasia. J Allergy Clin Immunol 124(6):1311-1318. https:// doi.org/10.1016/j.jaci.2009.10.007

Michelucci A, Garcia-Castaneda M, Boncompagni S, Dirksen RT (2018) Role of STIM1/ORAI1-mediated store-operated $\mathrm{Ca}^{(2+)}$ entry in skeletal muscle physiology and disease. Cell Calcium 76:101-115. https://doi.org/10.1016/j.ceca.2018.10.004

Michelucci A, Boncompagni S, Pietrangelo L, Garcia-Castaneda M, Takano T, Malik S, Dirksen RT, Protasi F (2019) Transverse tubule remodeling enhances Orai1-dependent $\mathrm{Ca}^{(2+)}$ entry in skeletal muscle. Elife. https://doi.org/10.7554/eLife.47576

Michelucci A, Boncompagni S, Pietrangelob L, Takano T, Protasi F, Dirksen RT (2020) Pre-assembled $\mathrm{Ca}^{2+}$ entry units and constitutively-active $\mathrm{Ca}^{2+}$ entry in skeletal muscle of calsequestrin-1 knockout mice. J Gen Physiol. https://doi.org/10.1085/jgp.20201 2617(Accepted for publication)

Misceo D, Holmgren A, Louch WE, Holme PA, Mizobuchi M, Morales RJ, De Paula AM, Stray-Pedersen A, Lyle R, Dalhus B, Christensen G, Stormorken H, Tjonnfjord GE, Frengen E (2014) A dominant STIM1 mutation causes Stormorken syndrome. Hum Mutat 35(5):556-564. https://doi.org/10.1002/humu.22544

Moccia F, Dragoni S, Lodola F, Bonetti E, Bottino C, Guerra G, Laforenza U, Rosti V, Tanzi F (2012) Store-dependent $\mathrm{Ca}^{(2+)}$ entry in endothelial progenitor cells as a perspective tool to enhance cell-based therapy and adverse tumour vascularization. Curr Med Chem 19(34):5802-5818. https://doi. org/10.2174/092986712804143240

Moccia F, Zuccolo E, Poletto V, Turin I, Guerra G, Pedrazzoli P, Rosti V, Porta C, Montagna D (2016) Targeting stim and orai proteins as an alternative approach in anticancer therapy. Curr Med Chem 23(30):3450-3480. https://doi.org/10.2174/092986732366616 0607111220

Morin G, Biancalana V, Echaniz-Laguna A, Noury JB, Lornage X, Moggio M, Ripolone M, Violano R, Marcorelles P, Marechal D, Renaud F, Maurage CA, Tard C, Cuisset JM, Laporte J, Bohm J (2020) Tubular aggregate myopathy and Stormorken syndrome: Mutation spectrum and genotype/phenotype correlation. Hum Mutat 41(1):17-37. https://doi.org/10.1002/humu.23899

Nelson BR, Wu F, Liu Y, Anderson DM, McAnally J, Lin W, Cannon SC, Bassel-Duby R, Olson EN (2013) Skeletal musclespecific T-tubule protein STAC3 mediates voltage-induced $\mathrm{Ca}^{2+}$ release and contractility. Proc Natl Acad Sci U S A 110(29):11881-11886

Nesin V, Wiley G, Kousi M, Ong EC, Lehmann T, Nicholl DJ, Suri M, Shahrizaila N, Katsanis N, Gaffney PM, Wierenga KJ, Tsiokas L (2014) Activating mutations in STIM1 and ORAI1 cause overlapping syndromes of tubular myopathy and congenital miosis. Proc Natl Acad Sci U S A 111(11):4197-4202
Oddoux S, Zaal KJ, Tate V, Kenea A, Nandkeolyar SA, Reid E, Liu W, Ralston E (2013) Microtubules that form the stationary lattice of muscle fibers are dynamic and nucleated at Golgi elements. J Cell Biol 203(2):205-213

Okuma H, Saito F, Mitsui J, Hara Y, Hatanaka Y, Ikeda M, Shimizu T, Matsumura K, Shimizu J, Tsuji S, Sonoo M (2016) Tubular aggregate myopathy caused by a novel mutation in the cytoplasmic domain of STIM1. Neurol Genet 2(1):e50. https://doi. org/10.1212/NXG.0000000000000050

Ong HL, Subedi KP, Son GY, Liu X, Ambudkar IS (2019) Tuning store-operated calcium entry to modulate $\mathrm{Ca}(2+)$-dependent physiological processes. Biochim Biophys Acta Mol Cell Res 1866(7):1037-1045. https://doi.org/10.1016/j.bbamc r.2018.11.018

Onopiuk M, Brutkowski W, Young C, Krasowska E, Rog J, Ritso M, Wojciechowska S, Arkle S, Zablocki K, Gorecki DC (2015) Store-operated calcium entry contributes to abnormal $\mathrm{Ca}(2)(+)$ signalling in dystrophic mdx mouse myoblasts. Arch Biochem Biophys 569:1-9. https://doi.org/10.1016/j.abb.2015.01.025

Orci L, Ravazzola M, Le Coadic M, Shen WW, Demaurex N, Cosson P (2009) From the cover: STIM1-induced precortical and cortical subdomains of the endoplasmic reticulum. Proc Natl Acad Sci U S A 106(46): 19358-19362

Pan Z, Yang D, Nagaraj RY, Nosek TA, Nishi M, Takeshima H, Cheng H, Ma J (2002) Dysfunction of store-operated calcium channel in muscle cells lacking mg29. Nat Cell Biol 4(5):379-383. https ://doi.org/10.1038/ncb788

Pan Z, Brotto M, Ma J (2014) Store-operated $\mathrm{Ca}^{2+}$ entry in muscle physiology and diseases. BMB Rep 47(2):69-79. https://doi. org/10.5483/bmbrep.2014.47.2.015

Paolini C, Protasi F, Franzini-Armstrong C (2004) The relative position of RyR feet and DHPR tetrads in skeletal muscle. J Mol Biol 342(1):145-153. https://doi.org/10.1016/j.jmb.2004.07.035

Paolini C, Quarta M, Nori A, Boncompagni S, Canato M, Volpe P, Allen PD, Reggiani C, Protasi F (2007) Reorganized stores and impaired calcium handling in skeletal muscle of mice lacking calsequestrin-1. J Physiol 583(Pt 2):767-784

Paolini C, Quarta M, D’Onofrio L, Reggiani C, Protasi F (2011) Differential effect of calsequestrin ablation on structure and function of fast and slow skeletal muscle fibers. J Biomed Biotechnol 2011:634075. https://doi.org/10.1155/2011/634075

Perni S, Dynes JL, Yeromin AV, Cahalan MD, Franzini-Armstrong C (2015) Nanoscale patterning of STIM1 and Orai1 during store-operated $\mathrm{Ca}^{2+}$ entry. Proc Natl Acad Sci U S A 112(40):E5533-5542

Piazzesi G, Caremani M, Linari M, Reconditi M, Lombardi V (2018) Thick filament mechano-sensing in skeletal and cardiac muscles: a common mechanism able to adapt the energetic cost of the contraction to the task. Front Physiol 9:736. https://doi.org/10.3389/ fphys.2018.00736

Picard C, McCarl CA, Papolos A, Khalil S, Luthy K, Hivroz C, LeDeist F, Rieux-Laucat F, Rechavi G, Rao A, Fischer A, Feske S (2009) STIM1 mutation associated with a syndrome of immunodeficiency and autoimmunity. N Engl J Med 360(19):1971-1980. https://doi.org/10.1056/NEJMoa0900082

Pierobon-Bormioli S, Armani M, Ringel SP, Angelini C, Vergani L, Betto R, Salviati G (1985) Familial neuromuscular disease with tubular aggregates. Muscle Nerve 8(4):291-298. https://doi. org/10.1002/mus.880080405

Pietrangelo L, D'Incecco A, Ainbinder A, Michelucci A, Kern H, Dirksen RT, Boncompagni S, Protasi F (2015) Age-dependent uncoupling of mitochondria from $\mathrm{Ca} 2(+)$ release units in skeletal muscle. Oncotarget 6(34):35358-35371. https://doi.org/10.18632 /oncotarget.6139

Potier M, Gonzalez JC, Motiani RK, Abdullaev IF, Bisaillon JM, Singer HA, Trebak M (2009) Evidence for STIM1- and Orai1-dependent 
store-operated calcium influx through ICRAC in vascular smooth muscle cells: role in proliferation and migration. FASEB J 23(8):2425-2437

Prakriya M, Feske S, Gwack Y, Srikanth S, Rao A, Hogan PG (2006) Orai1 is an essential pore subunit of the CRAC channel. Nature 443(7108):230-233

Prins KW, Humston JL, Mehta A, Tate V, Ralston E, Ervasti JM (2009) Dystrophin is a microtubule-associated protein. J Cell Biol 186(3):363-369

Protasi F (2002) Structural interaction between RYRs and DHPRs in calcium release units of cardiac and skeletal muscle cells. Front Biosci 7:d650-658

Protasi F, Sun XH, Franzini-Armstrong C (1996) Formation and maturation of the calcium release apparatus in developing and adult avian myocardium. Dev Biol 173(1):265-278. https://doi. org/10.1006/dbio.1996.0022

Protasi F, Franzini-Armstrong C, Flucher BE (1997) Coordinated incorporation of skeletal muscle dihydropyridine receptors and ryanodine receptors in peripheral couplings of $\mathrm{BC} 3 \mathrm{H} 1$ cells. J Cell Biol 137(4):859-870. https://doi.org/10.1083/ jcb.137.4.859

Protasi F, Franzini-Armstrong C, Allen PD (1998) Role of ryanodine receptors in the assembly of calcium release units in skeletal muscle. J Cell Biol 140(4):831-842. https://doi.org/10.1083/ jcb.140.4.831

Putney JW Jr (1986) A model for receptor-regulated calcium entry. Cell Calcium 7(1):1-12

Rios E, Ma JJ, Gonzalez A (1991) The mechanical hypothesis of excitation-contraction (EC) coupling in skeletal muscle. J Muscle Res Cell Motil 12(2):127-135. https://doi.org/10.1007/bf017 74031

Roos J, DiGregorio PJ, Yeromin AV, Ohlsen K, Lioudyno M, Zhang S, Safrina O, Kozak JA, Wagner SL, Cahalan MD, Velicelebi G, Stauderman KA (2005) STIM1, an essential and conserved component of store-operated $\mathrm{Ca}^{2+}$ channel function. J Cell Biol 169(3):435-445

Rosenberg P, Hawkins A, Stiber J, Shelton JM, Hutcheson K, BasselDuby R, Shin DM, Yan Z, Williams RS (2004) TRPC3 channels confer cellular memory of recent neuromuscular activity. Proc Natl Acad Sci U S A 101(25):9387-9392. https://doi. org/10.1073/pnas.0308179101

Rossi AE, Dirksen RT (2006) Sarcoplasmic reticulum: the dynamic calcium governor of muscle. Muscle Nerve 33(6):715-731. https ://doi.org/10.1002/mus.20512

Rossi AE, Boncompagni S, Dirksen RT (2009) Sarcoplasmic reticulum-mitochondrial symbiosis: bidirectional signaling in skeletal muscle. Exerc Sport Sci Rev 37(1):29-35. https://doi. org/10.1097/JES.0b013e3181911fa4

Rossi AE, Boncompagni S, Wei L, Protasi F, Dirksen RT (2011) Differential impact of mitochondrial positioning on mitochondrial $\mathrm{Ca}^{(2+)}$ uptake and $\mathrm{Ca}^{(2+)}$ spark suppression in skeletal muscle. Am J Physiol Cell Physiol 301(5):C1128-1139

Rossi D, Barone V, Giacomello E, Cusimano V, Sorrentino V (2008) The sarcoplasmic reticulum: an organized patchwork of specialized domains. Traffic 9(7):1044-1049. https://doi.org/10.111 1/j.1600-0854.2008.00717.x

Sacchetto R, Volpe P, Damiani E, Margreth A (1993) Postnatal development of rabbit fast-twitch skeletal muscle: accumulation, isoform transition and fibre distribution of calsequestrin. J Muscle Res Cell Motil 14(6):646-653. https://doi.org/10.1007/BF001 41561

Saito A, Seiler S, Chu A, Fleischer S (1984) Preparation and morphology of sarcoplasmic reticulum terminal cisternae from rabbit skeletal muscle. J Cell Biol 99(3):875-885. https://doi. org/10.1083/jcb.99.3.875
Salviati G, Pierobon-Bormioli S, Betto R, Damiani E, Angelini C, Ringel SP, Salvatori S, Margreth A (1985) Tubular aggregates: sarcoplasmic reticulum origin, calcium storage ability, and functional implications. Muscle Nerve 8(4):299-306. https://doi. org/10.1002/mus.880080406

Schneider MF (1994) Control of calcium release in functioning skeletal muscle fibers. Annu Rev Physiol 56:463-484. https://doi. org/10.1146/annurev.ph.56.030194.002335

Schneider MF, Chandler WK (1973) Voltage dependent charge movement of skeletal muscle: a possible step in excitationcontraction coupling. Nature 242(5395):244-246. https://doi. org/10.1038/242244a0

Scott BT, Simmerman HK, Collins JH, Nadal-Ginard B, Jones LR (1988) Complete amino acid sequence of canine cardiac calsequestrin deduced by cDNA cloning. J Biol Chem 263(18):8958-8964

Sebastien M, Giannesini B, Aubin P, Brocard J, Chivet M, Pietrangelo L, Boncompagni S, Bosc C, Rendu J, Gory-Faure S, Andrieux A, Fourest-Lieuvin A, Faure J, Marty I (2018) Deletion of the microtubule-associated protein 6 (MAP6) results in skeletal muscle dysfunction. Skelet Muscle 8(1):30. https://doi.org/10.1186/ s13395-018-0176-8

Shen X, Franzini-Armstrong C, Lopez JR, Jones LR, Kobayashi YM, Wang Y, Kerrick WG, Caswell AH, Potter JD, Miller T, Allen PD, Perez CF (2007) Triadins modulate intracellular $\mathrm{Ca}^{(2+)}$ homeostasis but are not essential for excitation-contraction coupling in skeletal muscle. J Biol Chem 282(52):37864-37874

Shin DW, Pan Z, Kim EK, Lee JM, Bhat MB, Parness J, Kim DH, Ma $\mathrm{J}$ (2003) A retrograde signal from calsequestrin for the regulation of store-operated $\mathrm{Ca}^{2+}$ entry in skeletal muscle. J Biol Chem 278(5):3286-3292. https://doi.org/10.1074/jbc.M209045200

Silva-Rojas R, Treves S, Jacobs H, Kessler P, Messaddeq N, Laporte J, Bohm J (2019) STIM1 over-activation generates a multi-systemic phenotype affecting the skeletal muscle, spleen, eye, skin, bones and immune system in mice. Hum Mol Genet 28(10):1579-1593

Soboloff J, Rothberg BS, Madesh M, Gill DL (2012) STIM proteins: dynamic calcium signal transducers. Nat Rev Mol Cell Biol 13(9):549-565

Sparrow JC, Schock F (2009) The initial steps of myofibril assembly: integrins pave the way. Nat Rev Mol Cell Biol 10(4):293-298

Stiber J, Hawkins A, Zhang ZS, Wang S, Burch J, Graham V, Ward CC, Seth M, Finch E, Malouf N, Williams RS, Eu JP, Rosenberg P (2008) STIM1 signalling controls store-operated calcium entry required for development and contractile function in skeletal muscle. Nat Cell Biol 10(6):688-697

Stormorken H, Sjaastad O, Langslet A, Sulg I, Egge K, Diderichsen J (1985) A new syndrome: thrombocytopathia, muscle fatigue, asplenia, miosis, migraine, dyslexia and ichthyosis. Clin Genet 28(5):367-374. https://doi.org/10.1111/j.1399-0004.1985.tb022 09.x

Sun XH, Protasi F, Takahashi M, Takeshima H, Ferguson DG, Franzini-Armstrong C (1995) Molecular architecture of membranes involved in excitation-contraction coupling of cardiac muscle. J Cell Biol 129(3):659-671. https://doi.org/10.1083/jcb.129.3.659

Takeshima H, Komazaki S, Nishi M, Iino M, Kangawa K (2000) Junctophilins: a novel family of junctional membrane complex proteins. Mol Cell 6(1):11-22. https://doi.org/10.1016/s1097 $-2765(00) 00003-4$

Takeshima H, Hoshijima M, Song LS (2015) $\mathrm{Ca}^{(2)(+)}$ microdomains organized by junctophilins. Cell Calcium 58(4):349-356. https ://doi.org/10.1016/j.ceca.2015.01.007

Tang W, Ingalls CP, Durham WJ, Snider J, Reid MB, Wu G, Matzuk MM, Hamilton SL (2004) Altered excitation-contraction coupling with skeletal muscle specific FKBP12 deficiency. FASEB J 18(13):1597-1599. https://doi.org/10.1096/fj.04-1587fje 
Thornton AM, Zhao X, Weisleder N, Brotto LS, Bougoin S, Nosek TM, Reid M, Hardin B, Pan Z, Ma J, Parness J, Brotto M (2011) Store-operated $\mathrm{Ca}^{(2+)}$ entry (SOCE) contributes to normal skeletal muscle contractility in young but not in aged skeletal muscle. Aging (Albany NY) 3(6):621-634

Valle G, Vergani B, Sacchetto R, Reggiani C, De Rosa E, Maccatrozzo L, Nori A, Villa A, Volpe P (2016) Characterization of fast-twitch and slow-twitch skeletal muscles of calsequestrin 2 (CASQ2)-knock out mice: unexpected adaptive changes of fasttwitch muscles only. J Muscle Res Cell Motil 37(6):225-233. https://doi.org/10.1007/s10974-016-9463-3

Vielhaber S, Schroder R, Winkler K, Weis S, Sailer M, Feistner H, Heinze HJ, Schroder JM, Kunz WS (2001) Defective mitochondrial oxidative phosphorylation in myopathies with tubular aggregates originating from sarcoplasmic reticulum. J Neuropathol Exp Neurol 60(11):1032-1040. https://doi.org/10.1093/ jnen/60.11.1032

Vig M, Peinelt C, Beck A, Koomoa DL, Rabah D, Koblan-Huberson M, Kraft S, Turner H, Fleig A, Penner R, Kinet JP (2006) CRACM1 is a plasma membrane protein essential for store-operated $\mathrm{Ca}^{2+}$ entry. Science 312(5777):1220-1223

Walter MC, Rossius M, Zitzelsberger M, Vorgerd M, Muller-Felber W, Ertl-Wagner B, Zhang Y, Brinkmeier H, Senderek J, Schoser B (2015) 50 years to diagnosis: Autosomal dominant tubular aggregate myopathy caused by a novel STIM1 mutation. Neuromuscul Disord 25(7):577-584. https://doi.org/10.1016/j. nmd.2015.04.005

Wang L, Zhang L, Li S, Zheng Y, Yan X, Chen M, Wang H, Putney JW, Luo D (2015) Retrograde regulation of STIM1-Orai1 interaction and store-operated $\mathrm{Ca}^{2+}$ entry by calsequestrin. Sci Rep 5:11349

Ward CW, Prosser BL, Lederer WJ (2014) Mechanical stretchinduced activation of ROS/RNS signaling in striated muscle. Antioxid Redox Signal 20(6):929-936. https://doi.org/10.1089/ ars.2013.5517

Wei-Lapierre L, Carrell EM, Boncompagni S, Protasi F, Dirksen RT (2013) Orai1-dependent calcium entry promotes skeletal muscle growth and limits fatigue. Nat Commun 4:2805

Westerblad H, Allen DG (2011) Emerging roles of ROS/RNS in muscle function and fatigue. Antioxid Redox Signal 15(9):2487-2499. https://doi.org/10.1089/ars.2011.3909

Wu MM, Buchanan J, Luik RM, Lewis RS (2006) $\mathrm{Ca}^{2+}$ store depletion causes STIM1 to accumulate in ER regions closely associated with the plasma membrane. J Cell Biol 174(6):803-813

Xiao B, Coste B, Mathur J, Patapoutian A (2011) Temperature-dependent STIM1 activation induces $\mathrm{Ca}(2)+$ influx and modulates gene expression. Nat Chem Biol 7(6):351-358

Yang T, Allen PD, Pessah IN, Lopez JR (2007) Enhanced excitationcoupled calcium entry in myotubes is associated with expression of RyR1 malignant hyperthermia mutations. J Biol Chem 282(52):37471-37478
Yano K, Zarain-Herzberg A (1994) Sarcoplasmic reticulum calsequestrins: structural and functional properties. Mol Cell Biochem 135(1):61-70. https://doi.org/10.1007/BF00925961

Yarotskyy V, Dirksen RT (2012) Temperature and RyR1 regulate the activation rate of store-operated $\mathrm{Ca}^{(2)+}$ entry current in myotubes. Biophys J 103(2):202-211. https://doi.org/10.1016/j. bpj.2012.06.001

Yarotskyy V, Protasi F, Dirksen RT (2013) Accelerated activation of SOCE current in myotubes from two mouse models of anesthetic- and heat-induced sudden death. PLoS One 8(10):e77633. https://doi.org/10.1371/journal.pone.0077633

Yeromin AV, Zhang SL, Jiang W, Yu Y, Safrina O, Cahalan MD (2006) Molecular identification of the CRAC channel by altered ion selectivity in a mutant of Orai. Nature 443(7108):226-229

Zhang L, Kelley J, Schmeisser G, Kobayashi YM, Jones LR (1997) Complex formation between junctin, triadin, calsequestrin, and the ryanodine receptor. Proteins of the cardiac junctional sarcoplasmic reticulum membrane. J Biol Chem 272(37):2338923397. https://doi.org/10.1074/jbc.272.37.23389

Zhang L, Wang L, Li S, Xue J, Luo D (2016) Calsequestrin-1 regulates store-operated $\mathrm{Ca}^{2+}$ entry by inhibiting STIM1 aggregation. Cell Physiol Biochem 38(6):2183-2193

Zhang SL, Yu Y, Roos J, Kozak JA, Deerinck TJ, Ellisman MH, Stauderman KA, Cahalan MD (2005) STIM1 is a $\mathrm{Ca}^{2+}$ sensor that activates CRAC channels and migrates from the $\mathrm{Ca}^{2+}$ store to the plasma membrane. Nature 437(7060):902-905

Zhao X, Weisleder N, Thornton A, Oppong Y, Campbell R, Ma J, Brotto M (2008) Compromised store-operated $\mathrm{Ca}^{2+}$ entry in aged skeletal muscle. Aging Cell 7(4):561-568

Zhao X, Min CK, Ko JK, Parness J, Kim DH, Weisleder N, Ma J (2010) Increased store-operated $\mathrm{Ca}^{2+}$ entry in skeletal muscle with reduced calsequestrin-1 expression. Biophys J 99(5):15561564. https://doi.org/10.1016/j.bpj.2010.06.050

Zhao X, Moloughney JG, Zhang S, Komazaki S, Weisleder N (2012) Orai1 mediates exacerbated $\mathrm{Ca}^{(2+)}$ entry in dystrophic skeletal muscle. PLoS One 7(11):e49862. https://doi.org/10.1371/journ al.pone. 0049862

Zitt C, Strauss B, Schwarz EC, Spaeth N, Rast G, Hatzelmann A, Hoth M (2004) Potent inhibition of $\mathrm{Ca}^{2+}$ release-activated $\mathrm{Ca}^{2+}$ channels and T-lymphocyte activation by the pyrazole derivative BTP2. J Biol Chem 279(13):12427-12437. https://doi. org/10.1074/jbc.M309297200

Publisher's Note Springer Nature remains neutral with regard to jurisdictional claims in published maps and institutional affiliations. 